\title{
International to domestic price transmission in fourteen developing countries during the 2007-08 food crisis
}

\author{
Kenneth Baltzer*
}

March 2013

\begin{abstract}
This paper synthesizes the evidence on price transmission from international maize, rice and wheat markets to domestic markets in fourteen developing countries during the global food crisis in 2007-08. A great variation in the price transmission patterns is observed; from almost no price pass-through in China and India, over close relationship between international and domestic prices in Brazil and South Africa, to substantial domestic price overshooting in Ethiopia and Nigeria. Much of this variation can be explained by price stabilization policies, public policy failure, incomplete market integration, and coinciding domestic shocks.
\end{abstract}

Keywords: Price transmission, global food crisis, cereal prices JEL classification: F1, O5

Copyright (c) UNU-WIDER 2013

*University of Copenhagen, Institute of Food and Resource Economics, email: kb@foi.ku.dk

This study has been prepared within the UNU-WIDER project 'The Political Economy of Food Price Policy', directed by Per Pinstrup-Andersen.

UNU-WIDER gratefully acknowledges the financial contributions to the research programme from the governments of Denmark, Finland, Sweden, and the United Kingdom.

This publication was supported by an agreement with Cornell University Division of Nutritional Sciences under Subagreement No. 60891-9461. 


\section{Acknowledgements}

The author would like to thank all the authors of the fourteen case studies, upon which this synthesis is based, for their useful comments and quality control of an earlier version of this paper. Also, the paper has benefitted greatly from constructive input by Shane Bryan, Derrill Watson II, Per Pinstrup-Andersen and an anonymous reviewer. Finally, a special thanks to Per Pinstrup-Andersen for his encouragements and great patience throughout the process.

The World Institute for Development Economics Research (WIDER) was established by the United Nations University (UNU) as its first research and training centre and started work in Helsinki, Finland in 1985. The Institute undertakes applied research and policy analysis on structural changes affecting the developing and transitional economies, provides a forum for the advocacy of policies leading to robust, equitable and environmentally sustainable growth, and promotes capacity strengthening and training in the field of economic and social policy making. Work is carried out by staff researchers and visiting scholars in Helsinki and through networks of collaborating scholars and institutions around the world.

www.wider.unu.edu

publications@wider.unu.edu

UNU World Institute for Development Economics Research (UNU-WIDER)

Katajanokanlaituri 6 B, 00160 Helsinki, Finland

Typescript prepared by Anna-Mari Vesterinen at UNU-WIDER.

The views expressed in this publication are those of the author(s). Publication does not imply endorsement by the Institute or the United Nations University, nor by the programme/project sponsors, of any of the views expressed. 


\section{Introduction}

This paper synthesizes the evidence of price transmission from international markets to domestic markets during the 2007-08 food crisis. It covers the markets for three grain commodities; maize, wheat, and rice, in fourteen developing countries. It is based on a number of case studies, one for each country, undertaken in Bangladesh (Raihan 2013), Brazil (Mueller and Mueller 2012), China (Huang, Yang, and Rozelle 2013), Egypt (Ghoneim 2012), Ethiopia (Admassie 2013), Kenya (Nzuma 2013), India (Ganguli and Gulati 2013), Malawi (Chirwa and Chinsinga 2013), Mozambique (Nhate and Massingarela 2013), Nigeria (Olomola 2013), Senegal (Resnick 2013), South Africa (Kirsten 2012), Vietnam (Nguyen 2013) and Zambia (Chapoto 2012) as part of a project on the political economy of food price policy. 1

What is widely known as the global food crisis, designates a period from the early 2007 to the mid2008, during which the prices of a number of food commodities increased sharply. It was followed by a period of collapsing prices in the second half of 2008 (e.g., Headey and Fan 2010; Abbott and Borot de Battisti 2011; Baffes and Haniotis 2010; and Timmer 2010, for analyses of the causes and consequences of the food crisis). As many of the commodities, notably maize, rice, and wheat are traded internationally, the crisis quickly spread across the world.

However, not all countries were hit equally hard by the higher prices, as the degree of price transmission from international to domestic markets varied significantly across countries. In some of the countries included in the present sample, domestic prices followed international prices relatively closely, in some other countries, domestic prices hardly increased at all, and in still others, domestic prices changed by even more than their international equivalents. The case studies reviewed in this paper discuss a wide range of factors limiting price transmission, notably active stabilization policies and poor market integration due to high transportation costs and market imperfections. In several countries, domestic prices are largely unrelated to international prices and therefore reflect purely local shocks, such as harvest failures and political turmoil which are independent from, but coincide with, the global crisis.

The empirical literature on price transmission that has emerged since the crisis generally comes to similar conclusions. Abbott and Borot de Battisti (2011) investigate price transmission patterns for a number of African countries (including a few others, such as China and Brazil, for comparison) by plotting international and local commodity price indices and estimating price transmission elasticities. They find great variation in price transmission from almost none in China to virtually complete in Brazil. In Africa, countries like Nigeria and Ethiopia appear to be closely linked to the world markets, whereas most of the other countries show limited and/or lagged responses, suggesting that world market pressures are resisted by domestic market institutions. Abbott and Borot de Battisti also identify certain patterns, such as much greater price transmission for highly traded commodities (for instance rice) compared to non-tradable ones (millet and sorghum), and higher price transmission rates for import dependent countries, including rice in Senegal, Mali, Burkina Faso, Niger, Malawi, and Uganda, maize in Malawi and Uganda, and wheat in Ethiopia.

Such findings are supported by other studies on countries in Africa (Benson, Mugarura, and Wanda 2008; Cudjoe, Breisinger, and Diao 2010; Minot 2011), Asia (Dawe 2008; Robles 2011), and Latin America (de Janvry and Sadoulet 2010; Robles 2011).

\footnotetext{
1 The project 'The Political Economy of Food Price Policy' was co-ordinated by Cornell University, UNU-WIDER, and Copenhagen University. The country studies are available at: http://www.wider.unu.edu/research/currentprogramme/en_GB/Political-Economy-of-Food/
} 
Most African countries experienced commodity price increases which were lower than the international prices, but in a few countries, notably in Ethiopia and Malawi, food prices grew more rapidly than on the world market (Minot 2011). This suggests that other shocks than the world market prices were at play. Similarly, Benson et al. (2008) argue that the increasing food prices in Uganda could be better explained by domestic or regional factors (for instance, spill-overs from harvest shortfalls in neighbouring Kenya) rather than by the global food crisis.

Transmission of rice prices in Asia was limited in most cases, notably India, Philippines, and Vietnam (Dawe 2008). Interestingly, Dawe finds a relatively high degree of pass-through (64 per cent) in China, which is in stark contrast to the almost flat local prices shown by Abbott and Borot de Battisti (2011). It should be noted, however, that Dawe's paper was one of the first analysis on the global food crisis, and the prices of rice were only available up to the late 2007, i.e. before the international rice prices accelerated. Based on more recent data covering the international spike in rice prices, Robles (2011) finds that the pass-through of rice prices was actually lower in Bangladesh (34 per cent), a rice importer, than in Pakistan and Vietnam (around 51 per cent), two rice exporters.

Robles (2011) and de Janvry and Sadoulet (2010) report quite low price transmission elasticities in a number of Latin American countries (Costa Rica, Ecuador, El Salvador, Guatemala, Honduras, Mexico, Nicaragua, Panama, Peru, and the Dominican Republic). Indeed, in Nicaragua (maize), Honduras (maize), and the Dominican Republic (rice), the pass-through may even have been negative. In general, price transmission elasticities are estimated to be below 20 per cent, with notable exception being rice markets in Mexico (almost 50 per cent) and wheat-to-bread price transmission in Ecuador (just over 40 per cent).

Through a synthesis of the fourteen case studies, this paper provides an overview of the price transmission patterns experienced by the countries during the food crisis period. In order to present the evidence as clearly and transparently as possible, the data is summarized graphically by plotting monthly series of local maize, rice, and wheat prices against international benchmark prices. Additionally, the wealth of information offered by the case study authors is reviewed in an attempt to gather some broad insights into how food price policies, domestic institutions, and other factors affected price transmission.

\section{Conceptual framework}

\subsection{What is price transmission?}

The fundamental theoretical basis for price transmission is the law of one price (LOP) (Fackler and Goodwin 2001). The LOP can be written as

$$
\left|p_{w}-p_{d}\right| \leq t
$$

where $p_{w}$ and $p_{d}$ are the prices of a commodity on the world market and the domestic market respectively and $t$ represents the transaction costs associated with importing or exporting the commodity. 2 Equation (1) states that the gap between the international and the domestic prices of a commodity should never be larger than the transaction costs.

\footnotetext{
2 Transaction cost is a general concept used to capture a variety of pecuniary and non-pecuniary costs associated with trading, such as transportation costs, import tariffs, waste, spoilage and opportunity costs due to delays, profit margins, etc.
} 
The positive transaction costs effectively create a price band between import parity; $p_{w}+t$, and export parity, $p_{w}-t$. If domestic supply and demand conditions are such that the domestic price lies within the price band, no international trade is profitable. In contrast, if domestic supply is sufficiently large relative to demand to press domestic prices below export parity, incentives for international arbitrage should ensure that domestic prices do not stay too far below export parity for too long. Similarly, relatively tight domestic supplies which push domestic prices close to or above the import parity, should invite importers to satisfy the excess demand at import parity. In effect, if the domestic price is within the parity bounds and the commodity is non-traded, we would expect the domestic price to be determined by domestic supply and demand condition and be unrelated to international prices. Instead, if the commodity is traded, the LOP predicts a close relationship between the international and domestic prices.

In reality, the distinction between isolation from the international markets and world market integration is not as clear cut as the theoretical discussion above would suggest. For instance, Mozambique and Kenya are both import dependent in cereals, yet studies (e.g. Minot 2011) have found that these countries are poorly integrated with the world markets. In contrast, even isolated markets, like the maize market in Ethiopia, appear to display some long term relationship with the international markets (Loening, Durevall, and Birru 2009). In general, we are likely to find that domestic prices in all countries are determined by a mix of domestic factors as well as transmission from international prices. The relative strength of domestic versus international factors varies greatly from country to country depending on how well countries are integrated with the world market. The rest of this section discusses briefly a number of factors which may influence market integration.

\subsection{Imperfect market integration}

The most commonly cited reasons for imperfect price transmission are collected under the overall heading of imperfect market integration (e.g. Abbott and Borot de Battisti 2011). Essentially, transaction costs are so high that international price changes have little impact on domestic prices, and an access to global markets to smooth out local price shocks is restricted. High transaction costs cover high costs of transportation due to poor infrastructure (particularly if countries are landlocked), imperfectly competitive markets, regulatory costs, and tariffs as well as taxes.

The higher the transaction costs are, the more likely it is that domestic prices fall within the parity bounds and commodities are non-traded. This is often the case with some of the basic staples in subSaharan Africa (SSA), such as millet, sorghum, cassava, and teff, but it also sometimes happens with internationally traded commodities. In such cases, the LOP no longer applies and we should not expect significant price transmission across borders. Yet, sometimes it still takes place. Demand substitution may link non-traded with traded commodities. As the price of the traded commodity increases following an international price shock, demand may shift towards non-traded commodities resulting in higher prices on these as well. Such cross-commodity price transmission may be weak, as Resnick (2013) indicates in the case of Senegal, or relatively strong, as appeared to have been the case in Ethiopia (Rashid 2011).

In case of most countries, the trade status of an individual country tends to persist over time. Countries are often consistently either net importers, net exporters, or separated from international markets. There are, however, exceptions. For instance, due to improvements in agricultural productivity, Malawi has shifted from import dependence to becoming largely self-sufficient in maize (Chirwa and Chinsinga 2013). South Africa, which is a regional trade hub for many commodities, varies between being net importer and net exporter of maize. Such trade regime shifts complicate price transmission analysis. 
Moving from trading to non-trading status may disrupt the price transmission mechanism. Shifting from exporter to importer (or vice versa) may cause sharp changes in domestic prices independently from international price movements as the domestic price changes from export parity to import parity. Needless to say, considering the trade status and particularly changes in trade, the status is important for evaluating price transmission.

It should be noted that when markets are imperfectly integrated, the assessment of price transmission depends on how it is measured as well as on the nature of the transaction costs. Most studies estimate relative price transmission elasticities, given by $\rho=\frac{d p_{i}}{d p_{j}} \frac{p_{j}}{p_{i}}$ (e.g. Abbott and Borot de Battisti 2011), but it is also possible to calculate absolute price transmission ratios, defined as $r=\frac{d p_{i}}{d p_{j}}$. When transaction costs are high, these two measures lead to different conclusions. The rice market in Senegal provides a case in point. Between January 2007 and May 2008, the international price of rice rose by US\$644 and the Senegalese wholesale price grew by US\$580.3 Based on this evidence, we could conclude that most of the international price shock was transmitted to the domestic market. However, since the transaction costs (implied by the difference between the international and the domestic price) are relatively high, the international price change represents a 202 per cent increase, whereas the Senegalese price rose by only 129 per cent. Measured in absolute terms, price transmission between the international and the Senegalese rice markets is close to perfect (around 90 per cent), but the relative price transmission is just around 64 per cent.

Which measurement is the most appropriate depends on the nature of transaction costs. If transaction costs are fixed, the LOP implies that $r=1$ and $\rho<1$. In contrast, if transaction costs are proportional to prices, $t_{i j}=\tau_{i j} p_{i}$, perfect price transmission requires that $\rho=1$, while $r>1$ if the country imports the commodity - otherwise $r<1$. Whether transaction costs are fixed or proportional to prices is an empirical question. The answer is likely to vary from case to case, and will more likely than not be somewhere in between. Neither price transmission ratios nor elasticities are likely to be perfect measures of the true extent of price pass-through. However, a few observations on the nature of transaction costs are warranted.

On the one hand, international transport costs are generally found to be unrelated to the prices or quantities of the shipped commodities (Anderson and van Wincoop 2004; Hummels and Skiba 2004). On the other hand, freight rates happened to increase (along with oil prices) during the food crisis period independently of food prices. Hence, we should not be surprised to find widening gaps between domestic and international prices over this period.

Theoretically, the markups added by imperfectly competitive market participants are proportional to prices and inversely proportional to the price elasticity of demand (the more price sensitive the demand, the lower the markups). Due to Engel's law, demand tends to be relatively inelastic when consumers are at or close to subsistence level which implies that the costs imposed by imperfect competition may be particularly large in very poor countries (Adam 2011). The literature on price transmission also suggests that imperfect competition is an important explanation for price transmission asymmetries along the value chain (Meyer and von Cramon-Taubadel 2004), i.e., the

3 Data are obtained from FAOs Global Information and Early Warning System (GIEWS) food price database. The international price is the 'Bangkok Thai 100\% B' (according to FAO, the leading rice trade benchmark), and the Senegalese price is the retail price on imported rice in Dakar. 
observation that increasing prices are transmitted relatively strongly down the value chain, whereas lower prices are transmitted incompletely and/or with significant lag. Many of the case studies in the sample, notably for Egypt, South Africa, Bangladesh, Senegal, and Zambia (Chapoto 2012; Ghoneim 2012; Kirsten 2012; Raihan 2013; Resnick 2013), suggest that the domestic food supply chains are characterized by high concentration and non-competitive behaviour.

Public policies may heavily influence the degree of price transmission. All countries in the sample use fiscal regulatory instruments such as tariffs, subsidies, and value added tax (VAT), which directly add to or subtract from the transaction costs. Proportional ad valorem tariffs and taxes are most common, but fixed per unit (specific) tariffs also exist. Non-fiscal government market interventions, such as non-tariff trade barriers, parastatal grain traders (China, India, Vietnam, Ethiopia, Malawi, Zambia, and Egypt), and price controls (notably Senegal), disrupt the price transmission mechanisms in ways that are harder to generalize. Most countries responded to the global food crisis by expanding existing policies or introducing new regulations. The next section investigates in more detail these policy responses' likely impact on price transmission.

\section{Political intervention}

During and after the global food crisis period, most governments in developing countries pursued a range of policies in attempts to reduce the transmission of the higher international prices to the domestic markets or to limit their adverse consequences (e.g., Demeke, Pangrazio, and Maetz 2011, for a review). The fourteen case studies in the present sample describe similar policy responses. A detailed synthesis of the policies is provided by Bryan (2013) and will not be repeated here. However, as the political interventions are important for understanding the variations across countries in the price transmission patterns, I spend some effort in contemplating the likely impacts of policy responses on price transmission. The discussion is organized under three types of policies; trade policies, domestic policies, and macroeconomic policies. I end this section by briefly discussing issues surrounding design and implementation of policies.

\subsection{Trade policies}

Border policies were pursued by many of the countries in the form of export restrictions and reductions of import tariffs (see Tables 1 and 2). Export restrictions are discussed first and import tariff waivers second.

By restricting exports, governments sought to reduce or completely disrupt the link between the international and the domestic prices. Obviously, the policy is likely to have the greatest effect when the export restriction is binding, i.e., if the country is already exporting the commodity or would have done so in the absence of the restriction. This is not to say that export restrictions are necessarily ineffective for an importer. If a cereal importer's price stabilization policies are effective or the country experiences a bumper harvest, domestic prices may drop below export parity, thus creating incentives for exporting to neighbouring countries that are stabilizing local prices less aggressively. Still, a consistent food importer may face additional obstacles to changing trade status in the shortterm as prospective exporters need to establish new export channels, demonstrate compliance with quality standards, etc. (Dawe 2010).

As indicators of the bindingness of export restrictions and bans, Table 1 summarizes the quantity of exports relative to output (three-year average, over 2004-06), and the international price relative to the domestic price (at the international price peak). The first is meant to indicate the country's capacity to export and the second its incentive. The shaded areas in Table 1 indicate where export restrictions were imposed. 
Table 1: Export restriction indicators

\begin{tabular}{|c|c|c|c|c|c|c|}
\hline \multirow[b]{2}{*}{ Country } & \multicolumn{2}{|c|}{ Maize } & \multicolumn{2}{|c|}{ Rice } & \multicolumn{2}{|c|}{ Wheat } \\
\hline & $\begin{array}{c}\text { Export } \\
\%\end{array}$ & $\begin{array}{l}\text { Int./Dom. } \\
\text { price ratio }\end{array}$ & $\begin{array}{c}\text { Export } \\
\%\end{array}$ & $\begin{array}{l}\text { Int./Dom. } \\
\text { price ratio }\end{array}$ & $\begin{array}{c}\text { Export } \\
\%\end{array}$ & $\begin{array}{l}\text { Int./Dom. } \\
\text { price ratio }\end{array}$ \\
\hline Bangladesh & 0.0 & - & 0.0 & 2.3 & 0.0 & 1.0 \\
\hline Brazil & 8.1 & 1.1 & 1.6 & 0.8 & 17.4 & 0.6 \\
\hline China & 3.3 & - & 0.5 & 2.4 & 0.7 & - \\
\hline Egypt & 0.0 & 0.8 & 15.0 & 1.3 & 0.0 & 1.1 \\
\hline Ethiopia & 0.2 & 0.5 & 0.0 & - & 0.0 & 1.1 \\
\hline India & 4.9 & - & 3.4 & 2.7 & 1.3 & 1.7 \\
\hline Kenya & 0.5 & 0.7 & 0.9 & - & 0.4 & - \\
\hline Malawi & 0.3 & 1.0 & 1.9 & 0.9 & 43.0 & - \\
\hline Mozambique & 2.8 & - & 1.3 & 1.3 & 0.0 & - \\
\hline Nigeria & 0.0 & 0.5 & 0.0 & - & 0.0 & - \\
\hline Senegal & 0.0 & - & 31.4 & 1.4 & - & - \\
\hline South Africa & 10.6 & 1.1 & - & - & 1.9 & 0.9 \\
\hline Vietnam & 0.8 & - & 12.9 & 1.4 & - & - \\
\hline Zambia & 4.8 & 1.0 & 7.1 & 0.7 & 0.0 & 0.3 \\
\hline
\end{tabular}

Notes: numbers in bold on shaded background indicate export restriction. 'Export\%' is the value of exports as a fraction of production, 'Int/Dom price ratio' is international cereal price relative to the domestic price.

Source: own calculations based on FAOSTAT and FAO GIEWS food price database.

Export restrictions were implemented by China, Egypt, Ethiopia, India, Kenya, Malawi, Vietnam, and Zambia (e.g., Bryan 2013 and the individual case studies). They were, however, not likely to be equally binding everywhere. China, India, Vietnam, and Egypt appear to have had both the capacity (indicated by exports in the recent years) and the incentive (the international prices being higher than the domestic equivalents) to export rice, and in India's case, wheat. In contrast, it is doubtful that the export bans in Ethiopia and Kenya had much of an impact on price transmission. Although these countries have exported small quantities of maize in the recent past, the local prices have been much higher than the international prices. Malawi and Zambia are borderline cases: both have been exporting a small maize surplus to neighbouring countries recently. The domestic prices were roughly at par with international prices during the summer of 2008, whereas the prices in neighbouring countries, such as Mozambique and Kenya, were considerably higher. It is therefore quite possible that exports could have continued had the ban not been in effect (Chirwa and Chinsinga 2013 and Chapoto 2012 both report that some informal trade did take place in spite of the bans).

The countries reviewed here were not the only ones to restrict exports. Such policies were also pursued by Argentina, Cambodia, Kazakhstan, Pakistan, Russia, and Ukraine (Demeke et al. 2011). While possibly a rational response to high international prices from the perspective of an individual country, the combined effect of several countries' export restrictions had unintended consequences for international prices. Export restrictions by major exporters reduced the world market supply and put additional pressure on international prices. An analysis by Martin and Anderson (2012) finds that export restrictions alone could explain 45 per cent of the increase in the international rice price and up to 30 per cent of the observed rise in the world wheat prices, while Headey and Fan (2010) attribute almost the entire rice price spike and up to half of the wheat price shock to export restrictions. Martin and Anderson (2012) argue that this poses a collective action problem in which the intended outcome of individual export restrictions (i.e. lower domestic prices) is largely defeated when all countries pursue the same policy.

Suspending import tariffs may briefly halt or reverse the increase on domestic prices, but it will not sever the link to international prices. On the contrary, eliminating tariffs reduces transaction costs which may strengthen rather than weaken the market integration. Several countries suspended import 
tariffs on grains to partially compensate for the increasing international prices (Demeke et al. 2011). However, in many cases the tariffs were very low to begin with and hence the tariff waivers might only have had a marginal effect on price transmission. Table 2 presents data on the import dependence of the countries, measured as the value of imports as a share of total use along with the size of import tariffs applied just before the crisis (2005-06). Shaded areas indicate where tariffs were reduced or suspended as reported in the country studies.

Table 2: Tariff waiver impact indicators 4

\begin{tabular}{|c|c|c|c|c|c|c|}
\hline \multirow{2}{*}{ Country } & \multicolumn{2}{|c|}{ Maize } & \multicolumn{2}{|c|}{ Rice } & \multicolumn{2}{|c|}{ Wheat } \\
\hline & Import \% & Tariff \% & Import \% & Tariff \% & Import \% & Tariff \% \\
\hline Bangladesh & $\begin{array}{ll}1.7 \\
\end{array}$ & 0.0 & 1.7 & 5.5 & 79.8 & 6.0 \\
\hline Brazil & 1.4 & 7.9 & 3.6 & 11.6 & 52.9 & 5.0 \\
\hline China & 2.5 & 59.5 & 0.2 & 65.0 & 0.9 & 65.0 \\
\hline Egypt & 35.0 & 2.0 & 0.6 & 2.0 & 51.1 & 2.0 \\
\hline Ethiopia & 0.9 & 5.0 & 47.8 & 5.0 & 30.9 & 5.0 \\
\hline India & 0.0 & 60.2 & 0.0 & 80.0 & 0.0 & 100.0 \\
\hline Kenya & 9.4 & 44.5 & 92.8 & 35.0 & 61.7 & 35.0 \\
\hline Malawi & 1.1 & 0.0 & 4.5 & 10.0 & 101.5 & 0.0 \\
\hline Mozambique & 7.4 & 2.5 & 78.3 & 7.5 & 98.9 & 2.5 \\
\hline Nigeria & 0.0 & 5.0 & 18.9 & 50.0 & 98.3 & 5.0 \\
\hline Senegal & 21.0 & 5.0 & 72.3 & 10.0 & - & 5.0 \\
\hline South Africa & 0.9 & 0.0 & 103.3 & 0.0 & 42.0 & 2.0 \\
\hline Vietnam & 12.8 & 25.1 & 0.0 & 25.9 & - & 2.6 \\
\hline Zambia & 0.0 & 14.4 & 40.4 & 15.0 & 20.9 & 10.0 \\
\hline
\end{tabular}

Note: 'Import \%' is the value of cereal imports as a share of total use, and 'Tariff \%' is the trade weighted average at the 4-digit HS aggregation level.

Source: own calculations based on FAOSTAT and UNCTAD TRAINS database. Information on tariff waivers is obtained from the case studies.

Bangladesh, Egypt, and Senegal temporarily removed tariffs on rice and wheat, but they were already relatively low, between two and ten per cent, so the impact must have been modest. Tariffs were much higher in Kenya and Nigeria and the tariff waivers have likely softened the impact of the higher international prices. It is noteworthy that these two countries experienced significant domestic price shocks in spite of the policy responses (see Figures 8 and 9).

\subsection{Domestic policies}

Domestic policies cover interventions that are designed to adjust domestic prices directly (e.g., food subsidies, suspension of VAT, or direct price controls), policies implemented to increase domestic food supply (e.g., release of grains from strategic grain reserves and long-term improvements in agricultural production), and social protection policies. Investments in agriculture and other efforts to improve agricultural productivity are long-term measures which are unlikely to have a major effect on price transmission patterns within the food crisis period. Also, social protection policies (such as income transfers and food for work programmes) should not affect price transmission directly, although they may contribute to maintaining food demand (Demeke et al. 2011). These policies are therefore not the focus of this paper.

\footnotetext{
4 There are some inconsistencies between some of the numbers reported here and in the country studies as well as in external literature. For instance, Nhate and Massingarela (2013) report that Mozambique reduced tariffs from 25 per cent to 2.5 per cent, but according to the TRAINS database, tariffs were already at 2.5 per cent in 2005 and 2006 . Also, Demeke et al. (2011) mention that Nigeria reduced a 100 per cent import tariff on rice to 2.7 per cent, but in the TRAINS database rice tariffs were 50 per cent in 2006. For consistency, in case of conflicts, I have reported numbers from TRAINS.
} 
Food subsidies and elimination of domestic duties work largely the same way as tariff waivers, except that they affect domestically produced commodities and not just imported food. The impact of higher international prices on domestic retail price is reduced, but market integration should, if anything, be strengthened by the lower transaction costs. Such price support policies were attempted in Bangladesh, China, Egypt, Ethiopia, Kenya, Mozambique, Senegal, Vietnam, and Zambia (Bryan 2013), but it is not possible to get a complete overview of their likely impact. We have little information on the size of the subsidies and VATs, and we know generally little about the extent to which subsidies were applied (universally or specifically targeted).

Price controls may completely disrupt the price transmission mechanism if they are successfully enforced. Among the fourteen case study countries, only Ethiopia, Malawi, and Senegal attempted to control prices directly. The experiences of Malawi and Senegal demonstrate the difficulties associated with fixing prices when enforcement mechanisms are lacking. In Malawi, a price band was supposed to be maintained through open market grain procurement and sales by ADMARC, a parastatal trader, but the agency lacked the necessary funds for its operation (Chirwa and Chinsinga 2013). In Senegal, the government promised to subsidize rice distributors in return for observing the price ceiling, but the policy backfired when the government was unable to disburse the funds on time (Resnick 2013).

Releasing grain from public stocks should not by itself directly affect price transmission if domestic markets are perfectly integrated with the world market. Any excess supply at prevailing world market prices would simply be exported. However, if markets are imperfectly integrated, possibly as a result of export restrictions, expansion of domestic supply should help depress domestic prices.

An additional indirect effect is conceivable. Increasing domestic supply enables the country to import less or export more grain. This could relieve some pressure on foreign exchange reserves and result in a real appreciation (or smaller real depreciation) of the domestic currency. As a result, the increase on international prices has a smaller impact on the domestic price impact denominated in local currency (Adam 2011). In practice, this effect is likely to be marginal at best in most countries as grain trade is usually a small part of total international trade and as exchange rates are influenced by other factors, such as monetary policies. A possible exception is Ethiopia which experienced an acute shortage of foreign exchange (largely due to higher prices on imported oil) during the food crisis period (Admassie 2013).

Among the fourteen case study countries, Bangladesh, China, Ethiopia, India, and Nigeria attempted to expand domestic supply by releasing stocks. From the case studies alone it is difficult to evaluate the likely impact of such policies. Several of them do not specify exactly how much grain was released, and detailed information on responses by private traders is very hard to obtain. Several studies, notably the ones on Bangladesh, Egypt, Malawi, Senegal, and Zambia, report that private traders responded to their governments' attempts at stabilizing prices by hoarding grain. To provide some indication of stock operations (private and public) during the food crisis, Table 3 shows the combined stock variation in 2007 and 2008 as a percentage of total domestic supply. 
Table 3: Release of stocks indicators (\% of total domestic supply)

\begin{tabular}{l|r|r|r}
\hline Country & Maize & Rice & Wheat \\
\hline Bangladesh & - & $-\mathbf{4}$ & $\mathbf{- 1 5 . 0}$ \\
Brazil & 0.0 & 1.3 & -7.0 \\
China & -7.2 & 0.1 & $-\mathbf{3 . 0}$ \\
Egypt & 0.0 & -8.5 & -7.8 \\
Ethiopia & 2.0 & 0.3 & $\mathbf{0 . 0}$ \\
India & 0.0 & $-\mathbf{0 . 3}$ & $-\mathbf{8 . 9}$ \\
Kenya & 11.7 & -0.0 & 0.0 \\
Malawi & -9.1 & -3.2 & -56.2 \\
Mozambique & 9.0 & 4.1 & 41.1 \\
Nigeria & 0.0 & -26.7 \\
Senegal & 9.1 & -14.9 & 0.0 \\
South Africa & -7.2 & 0.1 & -3.0 \\
Vietnam & - & -4.2 & 0.0 \\
Zambia & 27.7 & 0.0 & 33.3 \\
\hline
\end{tabular}

Notes: in principle, the stock variations reported here reflect public stocks as well as private stocks held by producers, traders, and storage operators. However, in practice such data are not collected in all countries and many entries capture only public stocks (exactly which entries are not reported). The numbers should be interpreted with caution. Positive numbers represent net release of grain to the market, negative numbers refer to net stockpiling of grain.

Source: own calculations based on FAOSTAT food balance sheets.

Although the numbers should be interpreted with caution, certain sensible patterns can be identified. For instance, Kenya appears to have drawn relatively heavily on maize storage during the crisis which makes sense in a period of harvest failures (Nzuma 2013). Bangladesh, Egypt, Malawi, and Senegal apparently stockpiled grain during the period which is in line with what the respective case studies report (Chirwa and Chinsinga 2013; Ghoneim 2012; Raihan 2013; Resnick 2013), and in some cases the quantities seem to have been substantial. It is notable that Bangladesh, China, and India show net additions to national stocks, despite of reportedly having released public stocks during the period. Perhaps farmers and private traders countered the public releases by adding to private stocks. At any rate, the numbers suggest that the impact on prices in these countries could have been minimal. In Ethiopia and Nigeria stocks were drawn down, but in Ethiopia's case, the impact appears to have been marginal.

\subsection{Macroeconomic policies}

Macroeconomic policies, such as fiscal and monetary policies, tend to be blunt instruments for achieving food price stabilizing objectives. However, the food crisis and the food price policies discussed above have macroeconomic repercussions, so it is instructive to briefly review the role played by macroeconomic policies during the food crisis period.

Consider first fiscal policies. Attempting to stabilize food prices or alleviating the impacts of higher food prices is very expensive. Most of the food price policies pursued by the fourteen case study countries either reduce government revenue (suspension of import tariffs and VAT) or increase outlays (food subsidies, social transfers, and agricultural investments). They are not likely to be sustainable if needed for an extended period of time (Abbott and Borot de Battisti 2011). As a result, food price policies may temporarily reduce price transmission, but once fiscal constraints force governments to roll back the policies, the link between the international and the domestic prices is re-established, possibly with a lag. Several countries in the sample approached the fiscal limits during the crisis, partly due to aggressive grain market regulation. For instance, Egypt managed to expand relatively generous food subsidies by cutting other government expenses (such as fuel subsidies) (Ghoneim 2012), while price policies in Malawi and Senegal were rendered ineffective by lack of funds (Chirwa and Chinsinga 2013; Resnick 2013). 
Several of the case studies view the food crisis from a monetary perspective. Admassie (2013) suggests that relatively accommodating monetary policies in the years prior to the food crisis were responsible for a significant portion of the observed Ethiopian food price inflation. In addition, the food crisis also coincided with rising general inflation in India and Bangladesh (Ganguli and Gulati 2013; Raihan 2013). One of the key responses to the crisis in these countries was tightening monetary policy. In contrast, Brazil found room for loosening monetary policies slightly by extending public credit, despite a strong focus on anti-inflationary policies (Mueller and Mueller 2012).

Supply-driven price shocks (as opposed to demand-driven inflation) are notoriously difficult to handle using monetary policies, and the macroeconomic literature generally recommends that central banks avoid doing so (Adam 2011). Demand-driven inflation is generally associated with relatively high economic growth, and tighter monetary policies may reduce both pressures. In contrast, when higher prices are caused by restricted commodity supply, inflation is negatively correlated with growth and tight monetary policy may hit an economic growth rate which is already low.

In a theoretical fully flexible economy, monetary policies should not influence the price transmission mechanism. Demand-driven inflation would increase domestic cereal prices denominated in local currency, but the exchange rate would depreciate by the same rate thus cancelling the effect of inflation on prices measured in foreign currency (US\$). Economies are, however, not fully flexible and it is unlikely that exchange rate movements completely negate inflationary pressures, particularly in the short run. For instance, Ethiopia pursued a strongly inflationary monetary policy up to and during the food crisis period while placing strict controls on foreign exchange. As a result, the currency depreciated only marginally and the general inflationary pressures drove US\$denominated cereal prices higher (Minot 2011).

Exchange rate movements also greatly affect how US\$-denominated price increases are transmitted to local-currency prices (Abbott and Borot de Battisti 2011; Dawe 2008). In this paper, all price transmission evidence presented is measured in US\$ prices in order to fully concentrate on the price transmission mechanism. Still, it is worthwhile to briefly consider how exchange rate variations impacted on how domestic consumers experienced the food crisis. Consider for instance Brazil, where the price of maize rose by 122 per cent in US\$ terms between June 2006 and June 2008. However, as the Brazilian real appreciated relative to the US\$ over the same period, local currency denominated prices increased only by around 60 per cent. Most countries in the sample saw currency appreciation relative to the US\$ (although not to the extent that Brazil did), but there are also exceptions. Due to the inflationary monetary policies in Ethiopia, the birr depreciated during the food crisis period and the price of maize rose by 189 per cent in US\$ terms and 220 per cent when measured in local currency units. 5

\subsection{Policy implementation}

Policy interventions only work as intended if they are designed and implemented properly. Many of the case studies provide examples of interventions that have gone awry due to lack of information, poor government capacity and political concerns, or corrupt practices.

Policy makers do not operate in an environment of perfect information, particularly when dramatic events, such as the global food crisis, call for swift action. Many of the case studies indicate that

5 The numbers are own calculations based on price data obtained from the FAO GIEWS food price database and exchange rates from IMF financial statistics. 
government interventions based on poor information have been less effective or have even exacerbated the situation. For instance, incorrect harvest forecasts led the government of Vietnam to reduce the number of export licenses in a situation where Vietnam could have benefited from improved terms of trade (Nguyen 2013). In contrast, the government of Malawi apparently overestimated the maize harvest and entered an export contract with Zimbabwe that could not be filled (Chirwa and Chinsinga 2013). One of the key lessons learned by the South African government from an earlier local food crisis in 2002-03, was the importance of accurate and timely information which led the government to establish a network for monitoring food prices more closely (Kirsten 2012).

Whether or not appropriate policies are designed, many governments, particularly in SSA have limited capacity to properly implement the policies. Several of the case studies report that policies could not be enforced. For instance, substantial informal cross-border trade took place in Kenya, Malawi, and Zambia in violation of export bans (Chapoto 2012; Chirwa and Chinsinga 2013; Nzuma 2013). Malawi and Senegal imposed price controls, but they were largely ignored (Chirwa and Chinsinga 2013; Resnick 2013). Also, many of the policies pursued by the governments, such as food and input subsidies, import and VAT waivers, and social safety nets, put severe strain on the countries' fiscal resources.

An important constraint on policy implementation is the political economy of food price policy generating rent-seeking behaviour (for a more in-depth analysis of the political economy of food price policy, see Watson 2013). The political environment shapes the choice, specific design, and implementation of food price policies. For instance, in Malawi 'politics is maize' (Chirwa and Chinsinga 2013), and the food policies are often designed to improve the re-election prospects of the president. In Brazil, policies are shaped by the twin beliefs of social inclusion and aversion to inflation (Mueller and Mueller 2012). Policy implementation is also often influenced by politics and corruption. In Zambia, deeply rooted mistrust between the government and the private sector significantly delayed imports of maize and thus prolonged the domestic crisis (Chapoto 2012). In Nigeria, large quantities of imported rice procured by the government were meant to be distributed to the poor, but much of it ended in the control of well-connected cronies, including senators, emirs, and local monarchs (Olomola 2013).

\section{Price transmission patterns}

The local grain markets in each of the fourteen countries in the case study sample responded to the rising international grain prices in a variety of ways. Although no two stories are exactly the same, I attempt to identify some common patterns by classifying the fourteen countries into four categories; 'free traders', 'exporting stabilizers', 'importers', and 'the isolated'. This classification is based on an assessment of the local markets' exposure to international price shocks, largely determined by the countries' trade status and the strength and effectiveness of the food price policies pursued by the countries as detailed in the case studies. I chose the classification scheme to provide a rough guide to what kind of price transmission patterns we should expect to find. The classification is as follows:

1. Free traders: Brazil and South Africa are well-integrated into the global cereal markets as net importers, net exporters, or both (depending on harvests). They responded to the food crisis with few and relatively weak food price policies and we would therefore expect them to display a high degree of price transmission. As we will see, this is also largely what we find, although the picture is distorted a bit by trade regime shifts.

2. Exporting stabilizers: China, India, and Vietnam are all net exporters of rice, and they reacted forcefully to the rising international prices with strong food price policies. We would expect 
to see relatively weak price transmission in these countries as they have a powerful instrument, export restrictions, at their disposal. We find that in China and India these policies effectively stabilized local prices during the period, but the Vietnamese policies appeared to have had a limited impact.

3. Importers: Bangladesh, Egypt, Kenya, Mozambique, and Senegal are consistently dependent on imports of their main staples. They are exposed to international price volatility and in contrast to exporters they have very few means available for stabilizing local prices. Thus, we would expect price transmission to be relatively high. As we will see, the picture is rather mixed due to local factors and distorting policies.

4. The isolated: Ethiopia, Malawi, Nigeria, and Zambia are poorly integrated into global cereal markets and are largely self-sufficient in their main staple. In these cases, we would expect that domestic prices are primarily determined by local supply and demand factors and largely unrelated to global prices. Interestingly, we find that in spite of the countries' relatively isolated status, they all experienced sharply increasing food prices during the crisis period.

In the following, I summarize the price transmission patterns observed in the countries in these four groups, and discuss some of the main factors influencing the patterns. Ideally, this summary would present estimates of price transmission elasticities or ratios as described earlier. A commonly used methodology for estimating price transmission elasticities is the Error-Correction Model (ECM) (e.g., Minot 2011). This model allows the researcher to estimate the long-term co-movement of domestic and international prices as well as the short-term impacts of shocks. The model is wellsuited for analysing long periods of relatively normal price transmission patterns.

There are, however, technical and conceptual problems involved with such methods, when applied to the food crisis period. A primary concern is that the standard methods may not be strictly valid. 6 Also, the sudden burst in international (and often domestic) prices represents a sharp break from earlier periods of more normal price movements. If we were to estimate price transmission elasticities based on data covering the last decade or so, the estimates would represent a mix of normal price transmission patterns as well as the exceptional patterns observed during the food crisis period. How should such elasticities be interpreted? If we wanted to limit the price transmission estimates to the food crisis period (or explicitly account for this structural break), the estimates would be based on a relatively short (and volatile) time period, and it would not be sensible to talk about long-term co-movement of prices. Additionally, other issues, such as the proper demarcation of the food crisis period, determination of appropriate lag-length, and how to account for domestic and political factors, generate more questions than answers.

Although these issues may be solvable, such attempts are beyond the scope of this synthesis. Instead, to give as clear and transparent picture of the price transmission patterns as possible, I provide a graphical representation of the international and domestic prices, and discuss in a bit more detail the main factors influencing the patterns.

\subsection{Free traders}

The first group of countries consists of Brazil and South Africa. I call the group the free traders as both countries appear to be closely integrated into the world grain markets. In addition, they were pursuing fairly liberal food price policies during the crisis (as detailed in Mueller and Mueller 2012

6 Technically, the price series are likely to be strongly non-stationary during the food crisis period, even in firstdifference form, and standard inference methods may therefore not be valid. 
and Kirsten 2012). This is also reflected in the relatively close co-movement of local maize, rice and wheat prices with their international equivalents as illustrated in Figures 1, 2, and 3.

Figure 1: Maize prices in Brazil and South Africa

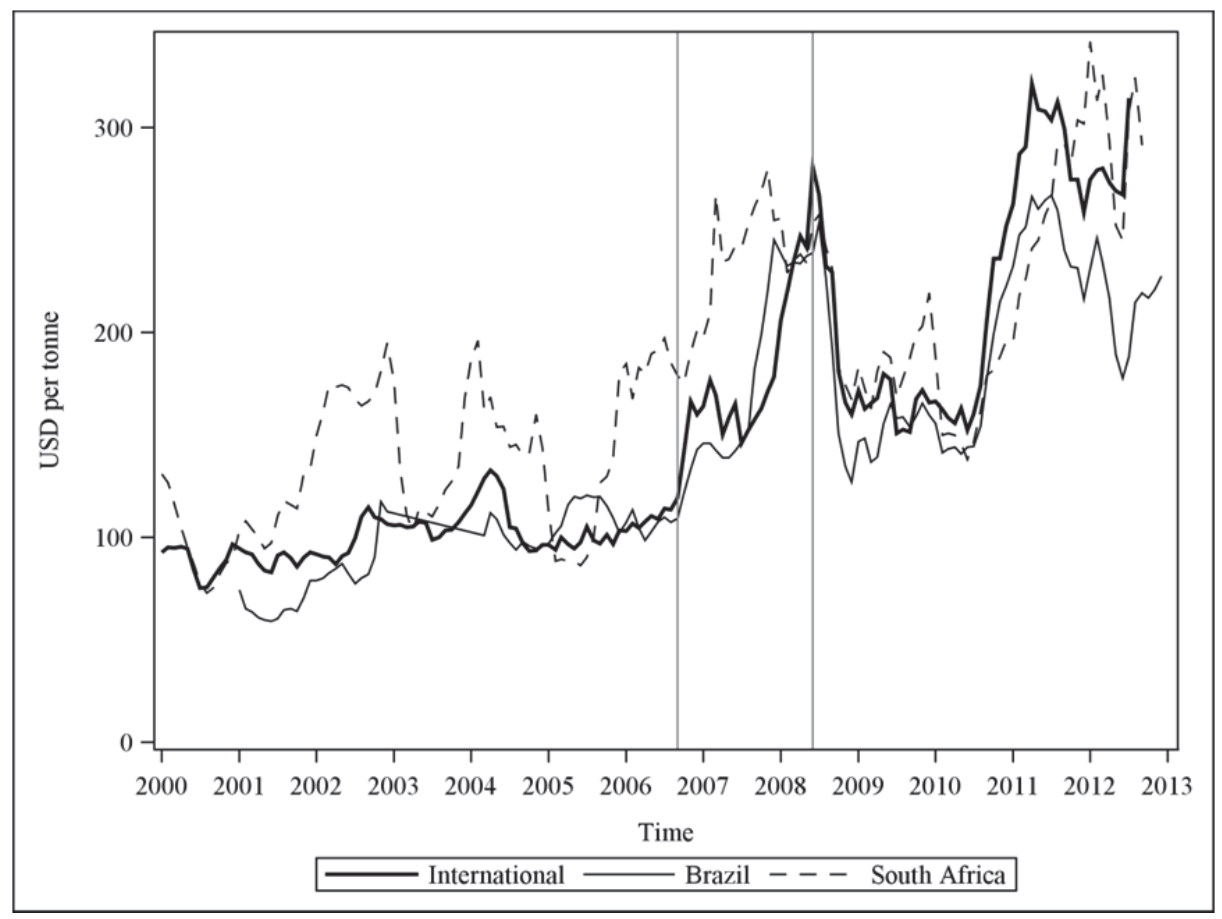

Source: FAO GIEWS food price database. International: 'US Gulf, no. 2',7 yellow maize. Brazil: national average, yellow maize, wholesale. South Africa: Randfontain, white maize, wholesale.

In most markets, the prices move close together. There are, however, a few exceptions. In South Africa, the price of maize seems to be a lot more volatile than the international prices. There are relatively large gaps between the South African and the international maize price in 2002, 2004, 2006, and the second half of 2007, but the gaps seem to disappear briefly in 2003, 2005, and 2008. The South African maize market is characterized by substantial variation in production around what is needed to satisfy demand (FAOSTAT 2013a). As a result, South Africa shifts continuously between being a net importer and a net exporter of maize. When South Africa is a net importer, as in 2002, 2004, 2006, and 2007 (according to data from FAOSTAT 2013b), the domestic price approaches import parity, whereas periods of net exports (2003, 2005, and 2008) drive prices towards export parity (NAMC 2007, 2009). Kirsten (2012) finds that when such trade regime shifts are accounted for, the evidence suggests that South African grain markets are highly integrated into the world markets.

7 US Gulf, no. 2 refers to the specific maize variety used to designate the international maize price. This is the most commonly used benchmark for an international maize price. 


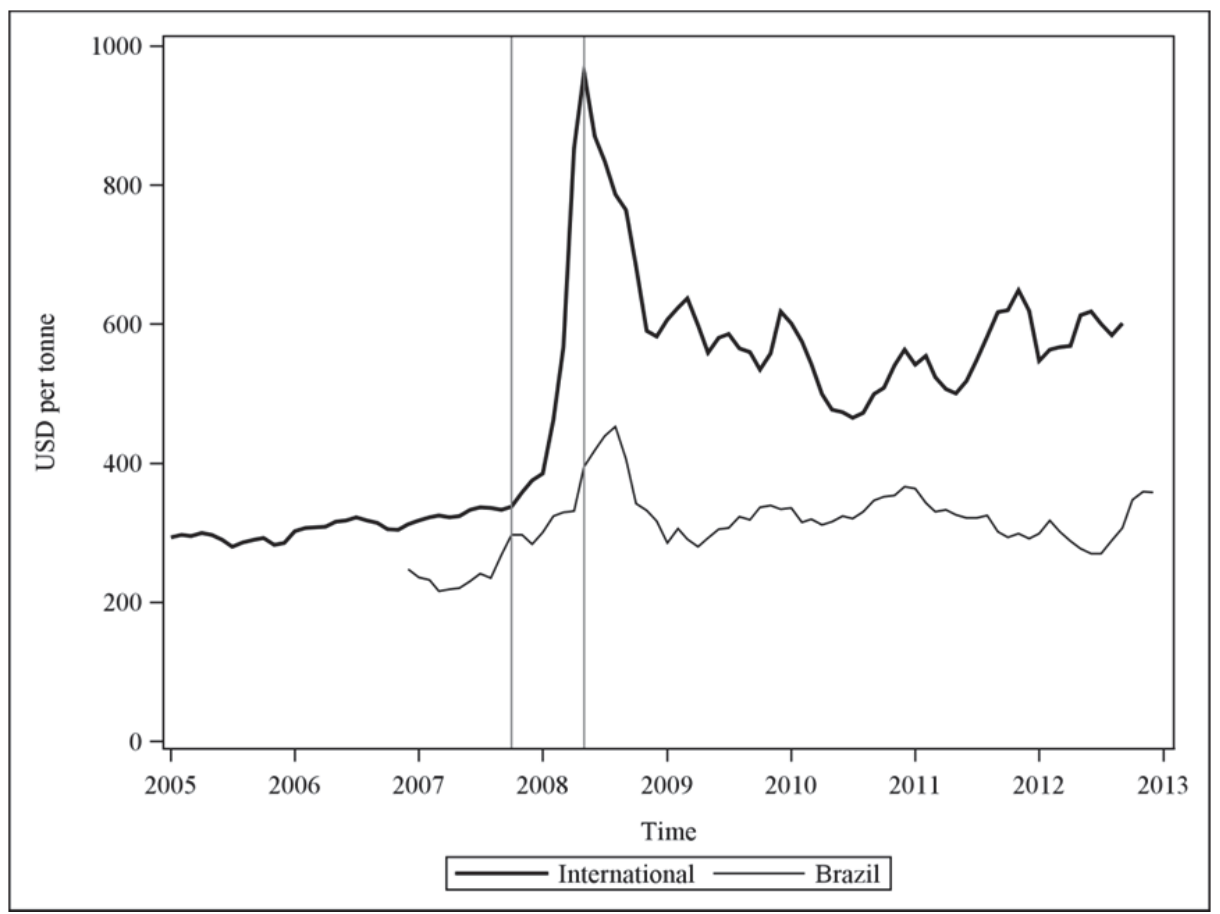

Source: FAO GIEWS food price database. International: Bangkok, 'Thai 100\% B'. 8 Brazil: national average, wholesale.

The only other market in this group which experienced regime shift during the crisis period is the Brazilian market for rice. Brazil is traditionally a rice net importer, but at the peak of the crisis in 2008, the country exported around 81,000 tons more than it imported, compared to a net import of 500,000 tons in 2007 (FAOSTAT 2013b). A shift in trade status could account for the relatively modest transmission of the international price peak as the domestic price declines (relative to international prices) from import parity towards export parity.

Both Brazil and South Africa are consistent net importers of wheat (FAOSTAT 2013b), so the domestic wheat prices tend to move closely with international prices (NAMC 2009). In Figure 3, discrepancies are evident during and after the global food crisis period, but the overall impression of substantial market integration remains.

8 Thai $100 \%$ B refers to the specific rice variety used to designate the international rice price. This is the most commonly used benchmark for an international rice price. 


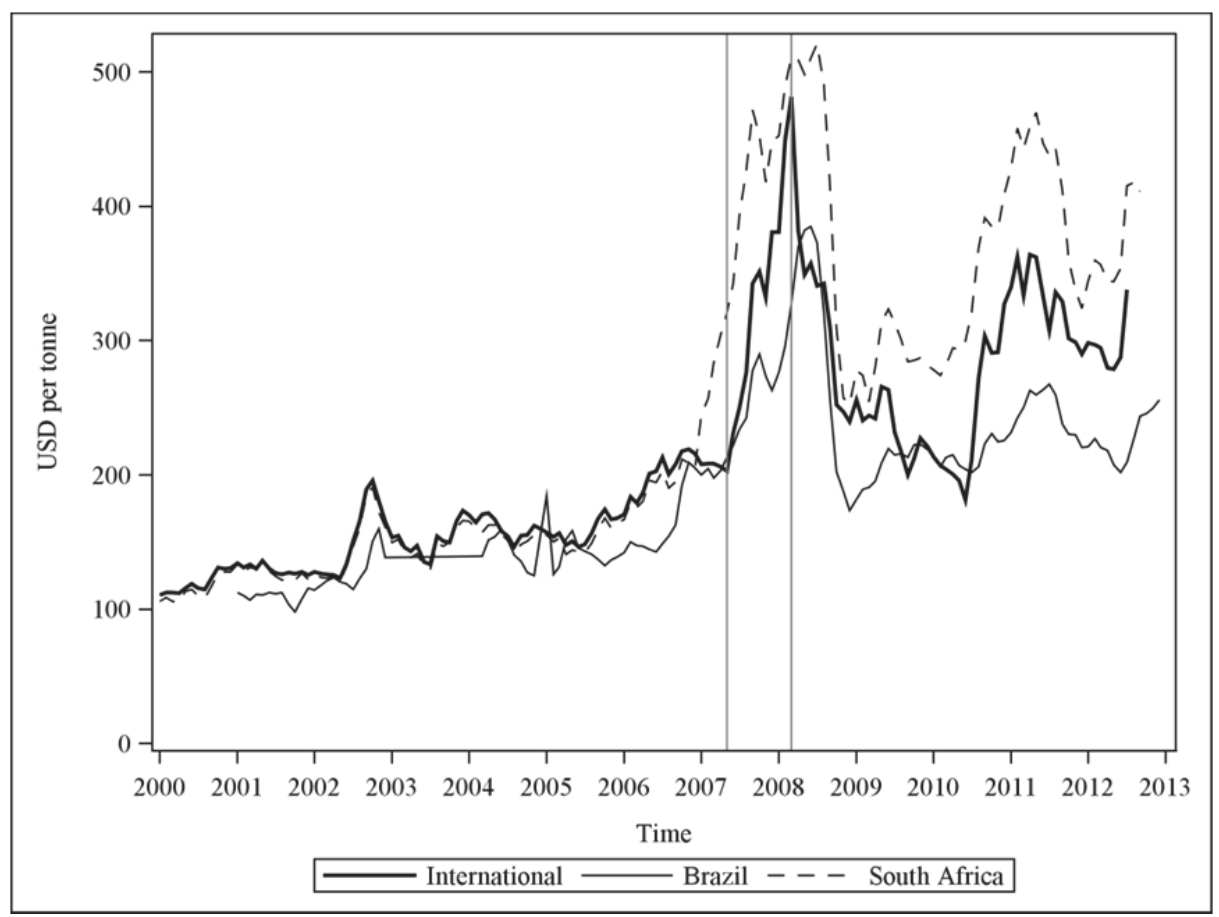

Source: FAO GIEWS food price database. International: US Gulf, no. 2, hard winter red. ${ }^{9}$ Brazil: national average, wholesale. South Africa: Randfontain, wholesale.

\subsection{Exporting stabilizers}

China and India successfully managed to stabilize local rice prices, primarily by banning exports. Vietnam also introduced export restrictions, but the stabilization policies were less effective. Common features of these three countries are that they are all net exporters of rice (India and Vietnam being two of the largest rice exporters in the world), and that grain trade tends to be heavily regulated. In India, most rice output is sold through the Food Corporation of India and other agencies and the grain markets are regulated by Minimum Support Prices (MSPs) (Ganguli and Gulati 2013). In China, the national supply chain is reportedly rather competitive, but international trade is carried out through state trading enterprises (Huang et al. 2013). The Vietnamese government each year specifies the maximum quantity of rice to be exported, and export quotas are distributed by the Vietnam Food Association, a centralized coalition of state-owned and private grain traders (Nguyen 2013). It therefore appears to have been relatively easy for these countries to control domestic grain supply, and stabilize prices. Evidence of this is illustrated in Figures 4 and 5.

9 US Gulf, no. 2, hard winter red refers to the specific wheat variety used to designate the international wheat price. This is the most commonly used benchmark for an international wheat price. 


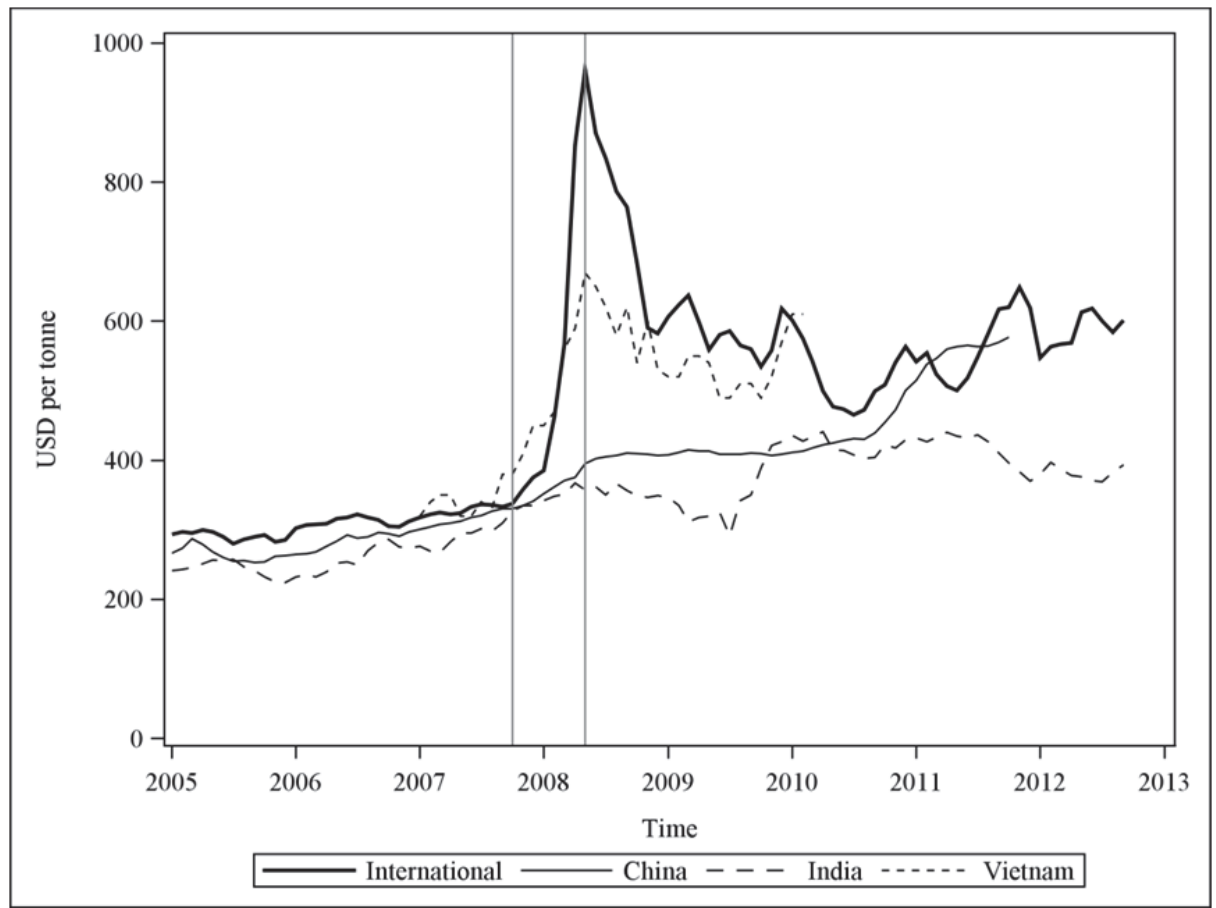

Source: FAO GIEWS food price database. International: Bangkok, Thai 100\% B. China: Hunan province, first quality, wholesale. India: Delhi, wholesale. Vietnam: Hanoi, retail.

Whereas the rice prices in China and India as well as wheat prices in India were virtually flat during the food crisis period, the price of rice in Vietnam did show a partially muted response to the surging international prices. One explanation may be that the Vietnamese prices are retail prices (wholesale prices were not available) which include additional marketing and profit margins. Another possibility is provided by Hai (2012): the Vietnamese government sets rice export limits (by advice of the Ministry of Agriculture and Rural Development (MARD)) based on projected rice surplus and not rice prices per se. In the spring of 2008, MARD forecast a lean rice crop which prompted the government to reduce the maximum export quota by one million tons to 3.5-4 million tons for 2008, and impose a temporary three-month moratorium on signing new export contracts. In any event, the projection turned out to be faulty and rice farmers produced a bumper crop. The Vietnamese policies took the tip off the price spike but were not sufficient in isolating the domestic market completely.

The Indian wheat and rice prices show an upward trend in the second half of 2009 (e.g., Figures 4 and 5). Ganguli and Gulati (2013) refer to this as a form of delayed price transmission. However, the increases in prices have less to do with (belated) transmission of price changes in the international market, but may be better explained by specific factors within India. India experienced relatively poor harvests in 2009, and following the food crisis of 2007-08, the government started to buy larger quantities of grain in an effort to expand the strategic grain reserves. Also, the MSPs for grains were adjusted upwards in the wake of the crisis, and the resulting higher farm gate prices were transmitted down through the value chain. 
Figure 5: Wheat prices in India

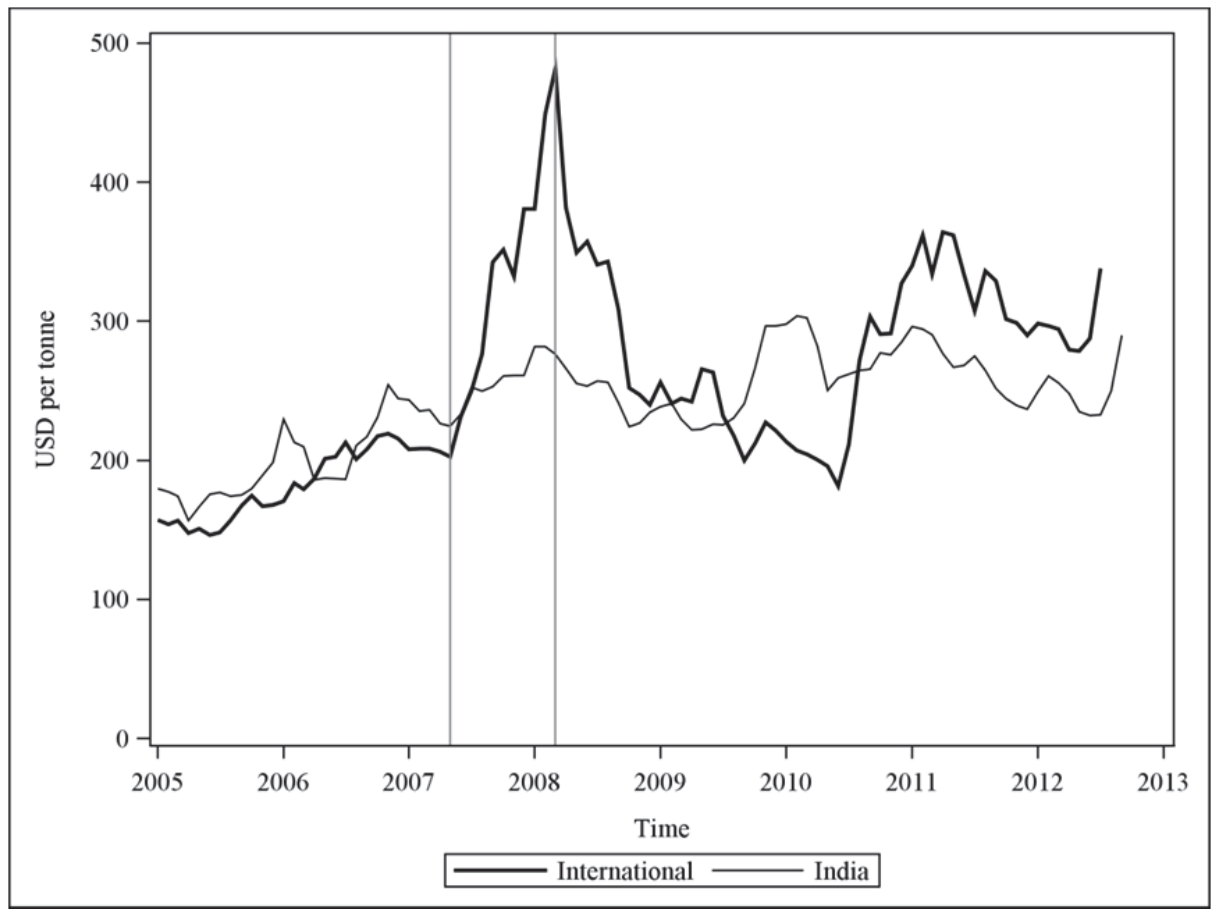

Source: FAO GIEWS food price database. International: US Gulf, no. 2, hard winter red. India: Delhi, wholesale.

\subsection{Importers}

Five countries in the sample, Bangladesh, Egypt, Kenya, Senegal, and Mozambique consistently depend on imports for the supply of their main staple, rice in Bangladesh and Senegal, wheat in Egypt, and maize in Kenya and Mozambique.

Figure 6: Rice prices in Bangladesh and Senegal

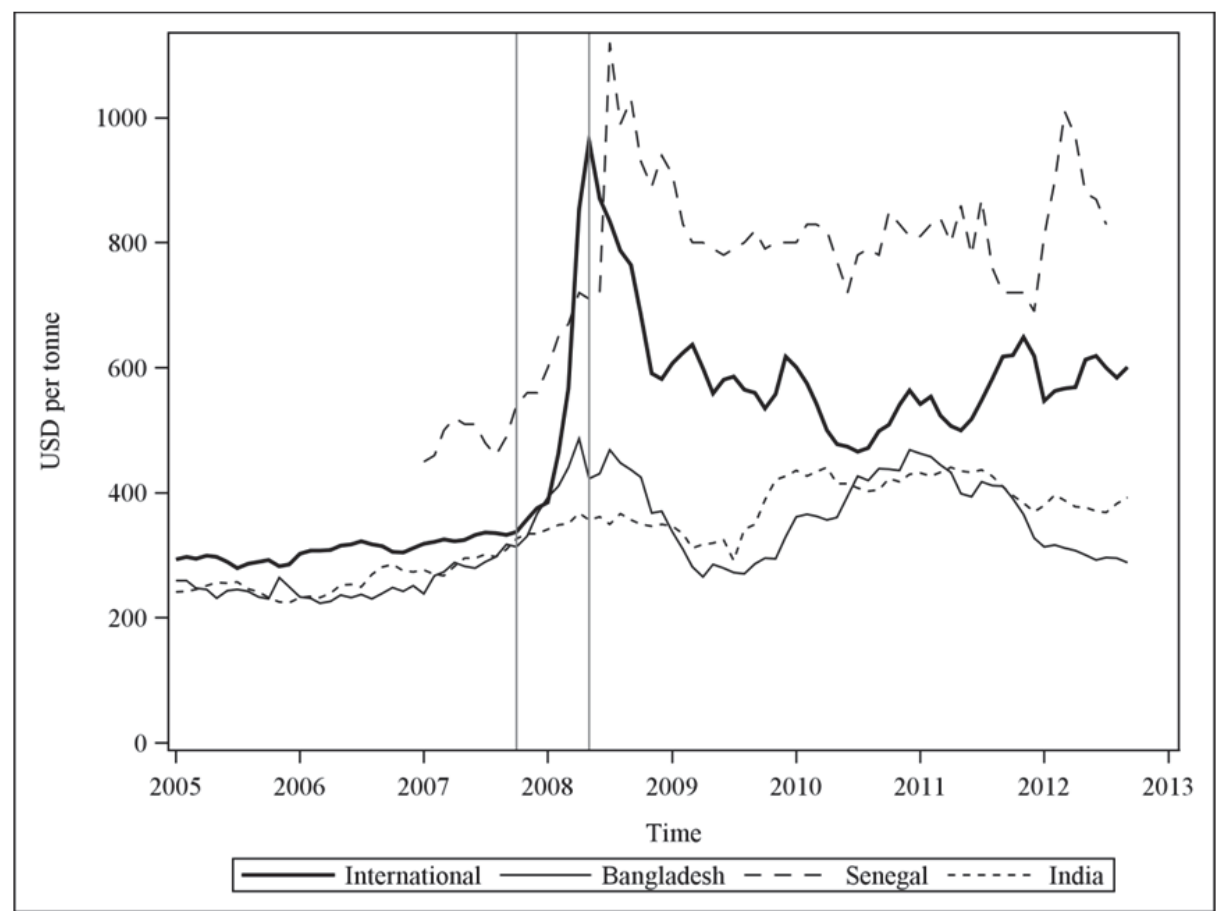

Source: FAO GIEWS food price database. International: Bangkok, Thai 100\% B. India: Delhi, wholesale. Bangladesh: Dhaka, wholesale. Senegal: Dakar, imported, retail. 
Figure 6 shows the rice prices in Bangladesh and Senegal plotted against the international prices. I have also included the Indian rice price as India is the main supplier of Bangladeshi rice imports (Hossain and Deb 2010). In fact, judging from Figure 6, the Bangladeshi rice price appears to be more closely related to the Indian price than the international (Thai export) price. Although both Senegal and Bangladesh were exposed to the international price volatility, they experienced the global crisis rather differently. In Bangladesh, the price shock is visible but quite modest. In Senegal, the rice price rose sharply and has stayed at a relatively high level ever since.

Rather than explaining why the rice prices increased in Bangladesh in the early 2008, a more interesting question is why they did not rise further. Raihan (2013) reports that the government in Bangladesh did seek to stabilize the rice prices but they had limited tools at their disposal. The most effective short-term policy response was the suspension of a 5 per cent import tariff on grains, which had at best a marginal effect. More importantly, Bangladesh managed to secure a supply of around half a million tons of rice from India in February 2008, just before the international price skyrocketed. However, it took a long time for the two governments to agree on a price and the first delivery arrived in April, just as the domestic rice harvest was about to hit the market (Hossain and Deb 2010). The 2008 season turned out to produce a bumper harvest, partly due to a massive supply response. In fact, for the first time in almost a decade, Bangladesh produced more than it used (FAOSTAT 2013a).

However, the question remains why private traders did not utilize the arbitrage opportunities and export rice from Bangladesh. The government did impose a ban on exports, but Dawe (2010) suggests that it had little effect in practice. As a traditional rice importer, Bangladesh lacks the capacity (in terms of quality assurance mechanisms and reputation) to export large quantities of rice in the short term.

Like Bangladesh, Senegal had few options available for reducing the impact of higher international rice prices. Import tariffs were already very low, and their suspension must have had little impact. To make matters worse, Senegal suffered two consecutive seasons of poor harvests in 2006-07 and 2007-08 due to shortages in agricultural inputs and irregular rainfall patterns (Resnick 2013). According to data from FAOSTAT (2013a), production in 2006 and 2007 was down almost 19 per cent compared to the average of the preceding three years. In response, the Senegalese government attempted to regulate rice prices directly. Senegal has had a long tradition of fixing bread prices, but as such price ceilings were extended to rice and other commodities, they could not be enforced and were therefore largely ignored. In response, the government struck an agreement with rice distributors by offering subsidies in return for lower retail prices. However, the subsidies turned out to be unsustainable and might actually have exacerbated the crisis. As the government was unable to pay out the subsidies on time, rice distributors started to stockpile rice in anticipation of future subsidy payments. As a result, rice prices continued to rise (Resnick 2013).

In the case of Egypt, it is difficult to assess the extent to which international prices were transmitted to domestic markets due to the lack of data: wholesale prices and retail prices are only available from January 2008 onwards. The evidence, shown in Figure 7, indicates a relatively stable retail price, but the apparent price stability was broken by short-lived spikes in late 2008, 2010, and 2011. The 2008 spike may represent a delayed response to the global food crisis; international wheat prices were also climbing in 2010 and 2011. Even so, any close relationship between international and Egyptian prices is not obvious. This rather mixed picture is consistent with the literature. Despite substantial wheat imports, Baffes and Gardner (2003) find that Egyptian wheat markets were very poorly integrated with global markets. However, Conforti (2004) and Rapsomanikis, Hallam, and Conforti (2006), show a long-term relationship between the Egyptian wholesale wheat prices and the 
international wheat prices after (but not before) 1989, despite strong regulation of Egyptian wheat markets.

Figure 7: Wheat prices in Egypt

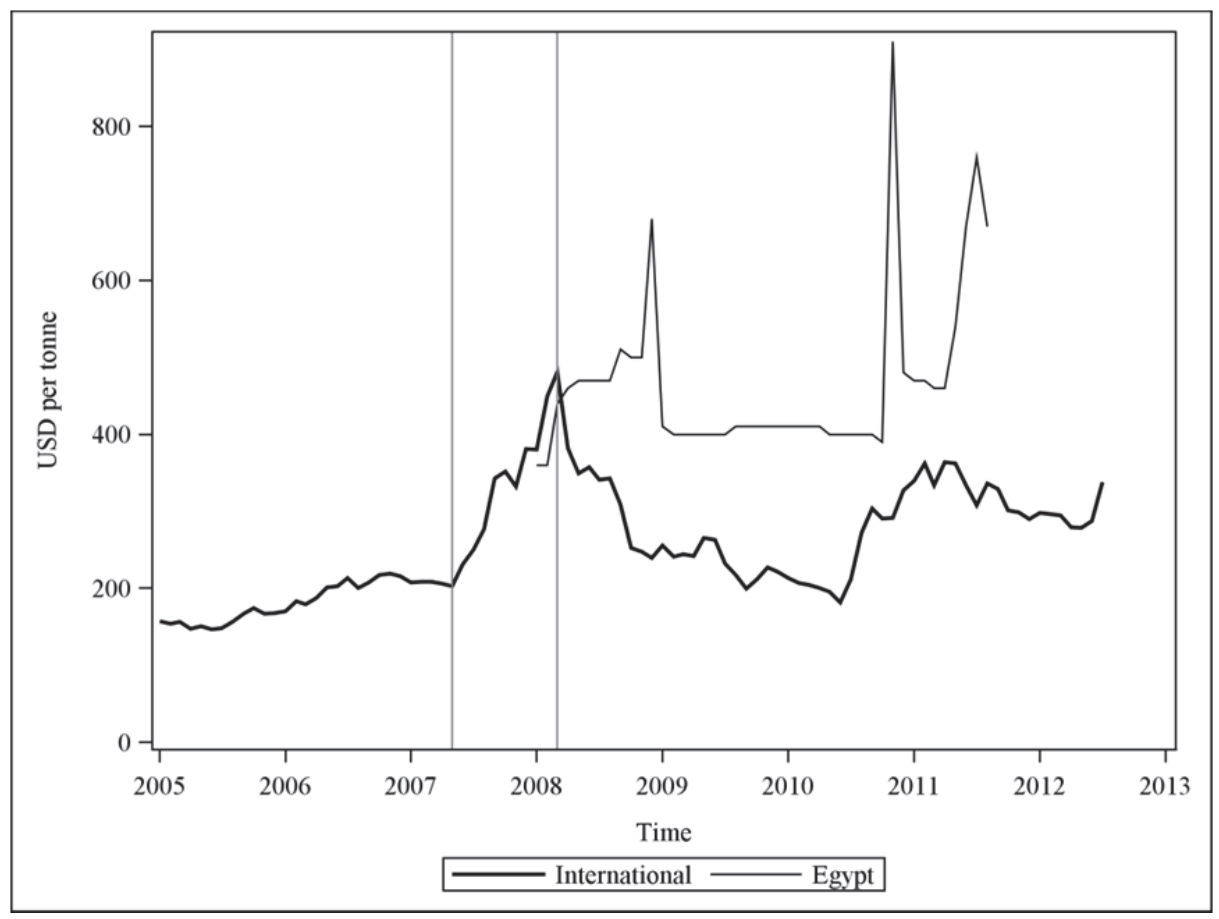

Source: FAO GIEWS food price database. International: US Gulf, no. 2, hard winter red. Egypt: Lower Egypt, retail.

Figure 8: Maize prices in Kenya and Mozambique

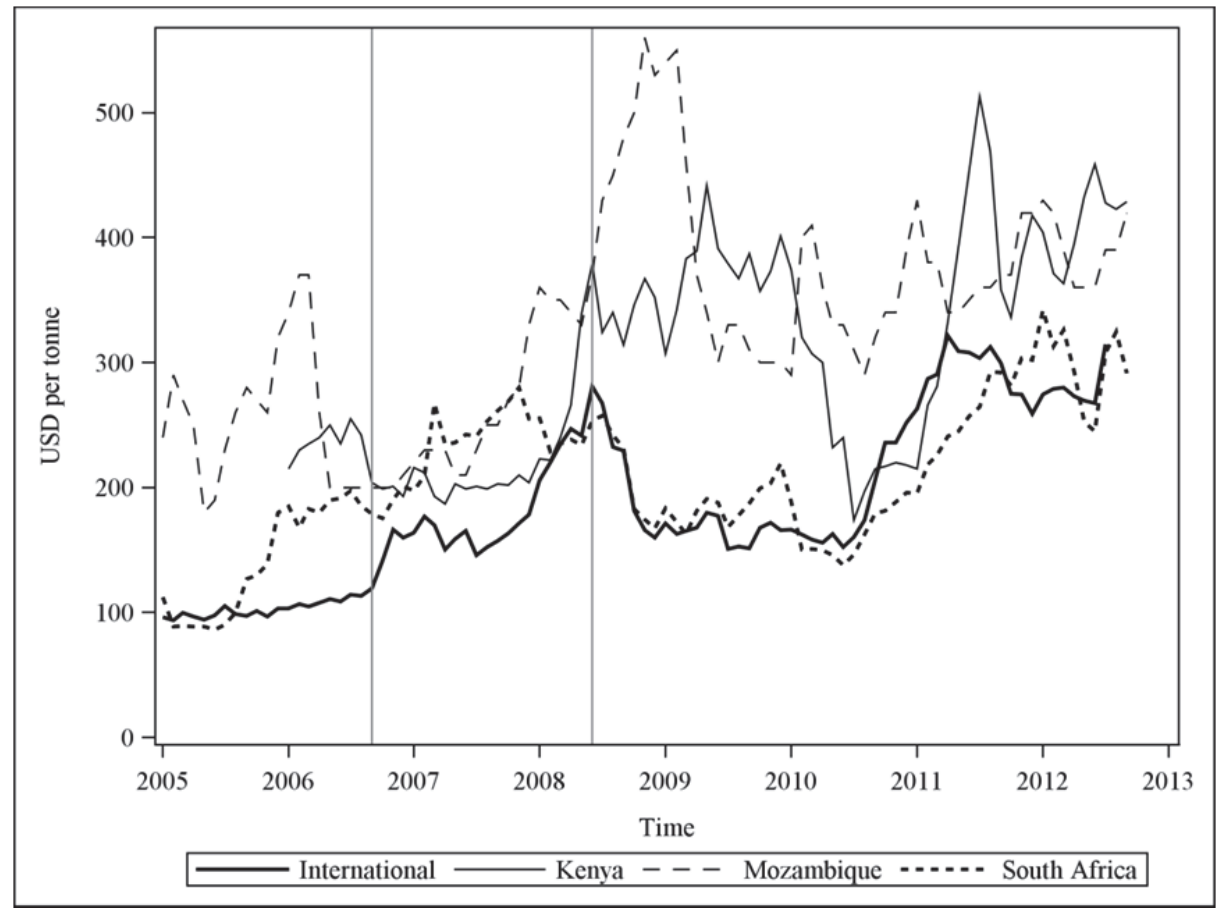

Source: FAO GIEWS food price database. International: US Gulf, no. 2, yellow maize. Kenya: Nairobi, wholesale. South Africa: Randfontain, white maize, wholesale.

An elaborate social protection infrastructure already existed in Egypt prior to the crisis. Large quantities of locally produced and imported wheat are procured by the General Agency for the 
Supply of Commodities (GASC, a government agency), milled in public mills, and processed in public bakeries into baladi bread which is sold in public shops at subsidized prices. In addition, a range of subsidized basic commodities (such as sugar, oil, and rice) are distributed to a large part of the population on the basis of ration cards. Although the social safety net is hugely expensive, inefficient, and mired by corruption and massive leakage, it does appear to have shielded the poor beneficiaries from the worst impact of the global food crisis (Ghoneim 2012).

Figure 8 shows the wholesale price of maize in Kenya and Mozambique, together with the international price and the maize wholesale price in South Africa, the main supplier of the two countries. The maize prices in Kenya and Mozambique rose substantially during the food crisis period but as the international and South African prices collapsed in the second half of 2008, domestic prices stayed at a high level. In the case of Mozambique, maize prices peaked half a year after the global crisis.

Closer inspection of the two countries suggests that domestic factors played a major role in the domestic maize price formation. Although Kenya and Mozambique are both consistent maize importers, Minot (2011) cannot find significant long-term relationship between the international (or South African) and domestic prices (however, he does find evidence of rice market integration in Mozambique).

In Kenya, several years of drought-induced poor harvests generated a need for large imports of maize in 2008 (Benson et al. 2008; Nzuma 2013). According to FAOSTAT (2013a), production in both 2008 and 2009 was down by 20 per cent compared to the average of the previous three years. As the developing global food crisis prompted neighbours, such as Tanzania and Malawi, to restrict their exports, the Kenyan government struggled to fill import orders throughout 2008. When the import needs were finally satisfied during 2009 (another drought-ridden year), imports of maize jumped from around 114,000 tons in 2007 and 244,000 tons in 2008 to 1.5 million tons in 2009 (FAOSTAT 2013b). Insofar as the massive increase in imports represents a buildup of an acute supply shortage, it is not surprising that the maize prices increased in 2008 and persisted throughout the year. What is, perhaps, surprising is that Kenya was unable to satisfy its import needs for such a long time in the aftermath of the global food crisis. Although the regional export bans stayed in effect throughout 2008, Kenya's main import supplier of maize was not Malawi or Tanzania but South Africa, which did not restrict maize exports. In fact, according to the data from the UN COMTRADE database, South Africa ended up supplying two-thirds of Kenya's maize imports in 2009.

The picture is not quite as clear in the case of Mozambique. FEWS NET (2009) reports that the country was hit by floods, rainfall deficits, and wildfires in different areas which affected harvests adversely. It is, however, not clear if these events were particularly severe compared to the earlier years. Maize harvests in 2007 and 2008 were around the same size as the average of the previous three years (FAOSTAT 2013a). Arndt et al. (2008) suggest that part of the domestic price shock was due to the unusually high international prices as the government did little to prevent price transmission (see also Nhate and Massingarela 2013). Also, part of the price volatility in Figure 8 seems to be seasonal. Prices tend to increase towards the 'hunger season' from October to January (FEWS NET 2009), as output from the second harvest is no longer available to cushion the prices (Arndt et al. 2008). The large price spike following the global price peak coincides with this period.

\subsection{The isolated}

Among the fourteen countries included in the sample, Ethiopia, Malawi, Nigeria, and Zambia are relatively isolated from the international cereal markets. Ethiopia experiences substantial variations in maize production over time (FAOSTAT 2013a), but domestic storage serves to close the gaps 
between production and use with little reliance on international trade (Tadesse and Guttormsen 2011). Demand for maize in Nigeria tends to follow domestic supply quite closely (FAOSTAT 2013a), although Nigeria is dependent upon imports of rice (Olomola 2013). Malawi and Zambia have traditionally depended on maize imports from neighbouring countries, but both countries recently managed to become largely self-sufficient in maize and even produced a small surplus for exports (Chapoto 2012; Chirwa and Chinsinga 2013; FAOSTAT 2013a, 2013b).

Figure 9: Maize prices in Ethiopia and Nigeria

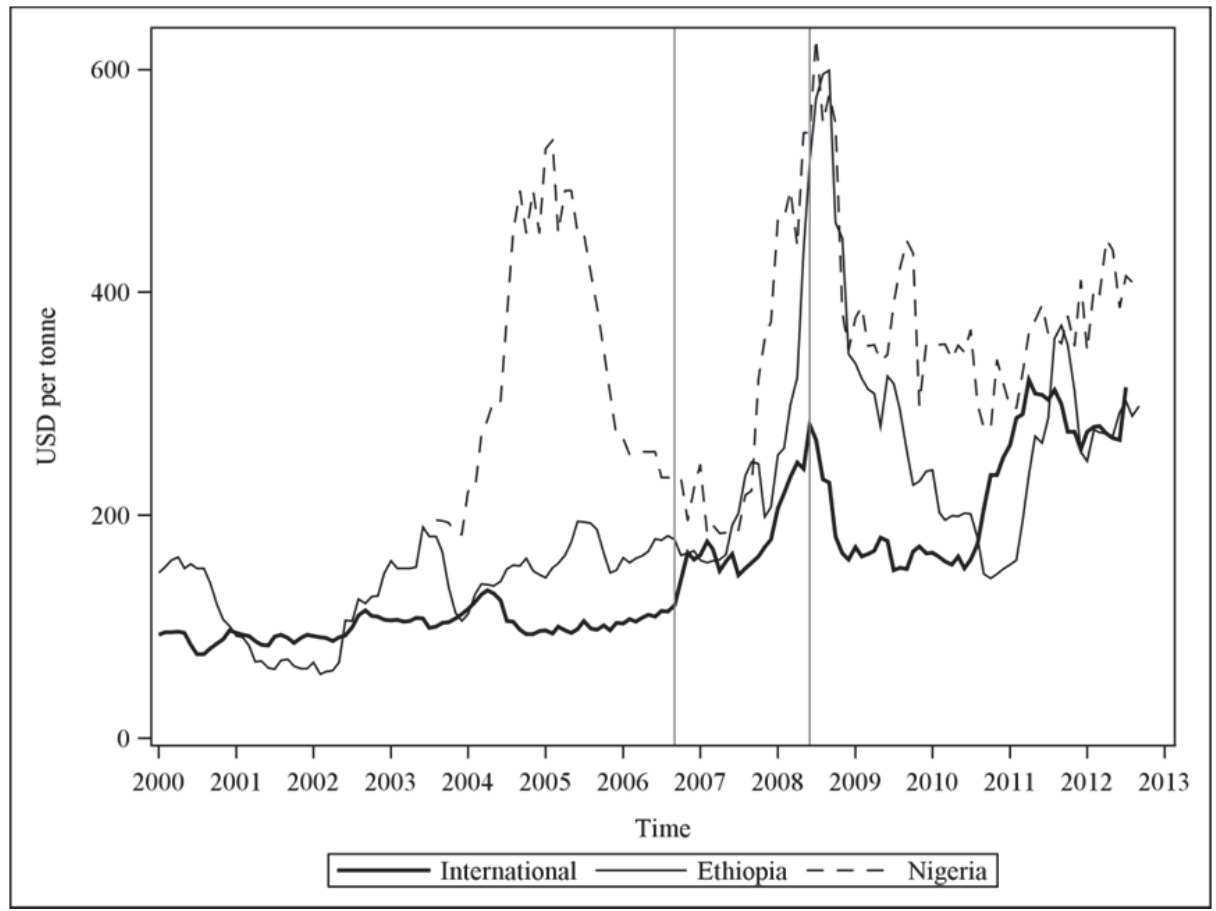

Source: FAO GIEWS food price database. International: US Gulf, no. 2, yellow maize. Ethiopia: Addis Ababa, wholesale. Nigeria: Kano, wholesale.

Figure 9 shows the maize prices in Ethiopia and Nigeria together with the international reference price. Both countries experience sharply increasing prices during the global food crisis period, but the domestic price spikes are substantially larger than the international price shock. It also takes longer for the domestic prices to come down again—especially in Nigeria.

There is some debate over the extent to which the Ethiopian food prices were driven by domestic factors or the international crisis. The isolated (and landlocked) nature of Ethiopia together with its very limited international food trade would suggest that domestic market should be fairly unrelated to international markets. However, the evidence appears to be mixed. In their empirical studies, Minot (2011) and Ulimwengu, Workneh, and Paulos (2009) find no long-run relationship between Ethiopian maize, sorghum, or wheat markets. In contrast, Loening et al. (2009) and Conforti (2004) do find long-run co-integration between the Ethiopian and international grain prices.

Admassie (2013) argues that the Ethiopian crisis was primarily caused by long-running domestic factors, such as increasing grain demand due to economic growth and more well-developed social safety nets, stagnating grain supply, and inflationary monetary policy. The trigger came in 2008, when the surging global energy prices led to a shortage of foreign exchange reserves which prompted the government to ration the foreign exchange available for other purposes such as imports of food. 
The inflationary monetary policy explanation for the observed food price inflation has gained a lot of traction, particularly among economists at the World Bank and the International Monetary fund (IMF) (Haji and Gelaw 2012). Foreign exchange controls prevented the currency from depreciating and rapidly rising prices denominated in domestic currency translated directly into high food inflation measured in US\$ (Minot 2011).

There is little doubt that Ethiopia experienced high and growing general inflation in 2007 and 2008. It is less clear, however, that food inflation was necessarily driven by demand fueled by expansionary monetary policies. Food inflation, particularly in cereal prices, was substantially higher than non-food inflation during the food crisis period (FAO/WFP 2009). While demand-driven inflation does not necessarily entail that all prices grow by the same rate, it is still remarkable that Ethiopia had the largest food inflation rate relative to non-food inflation in the developing world (3.5 per cent per month) in 2008, and negative relative food inflation in both 2009 and 2010 (Headey et al. 2012).

In the light of this discussion, it is unlikely that Ethiopian food prices were determined by solely domestic or international factors. In support of this assertion, Haji and Gelaw (2012) decompose food price inflation into different components and find that a number of factors affected domestic food prices, including domestic price level, world grain prices, domestic fuel prices, and non-food prices. Unfortunately, it is not straightforward to assess the relative weight of the different factors in forming domestic prices.

Figure 10: Maize, wheat, and teff prices in Ethiopia

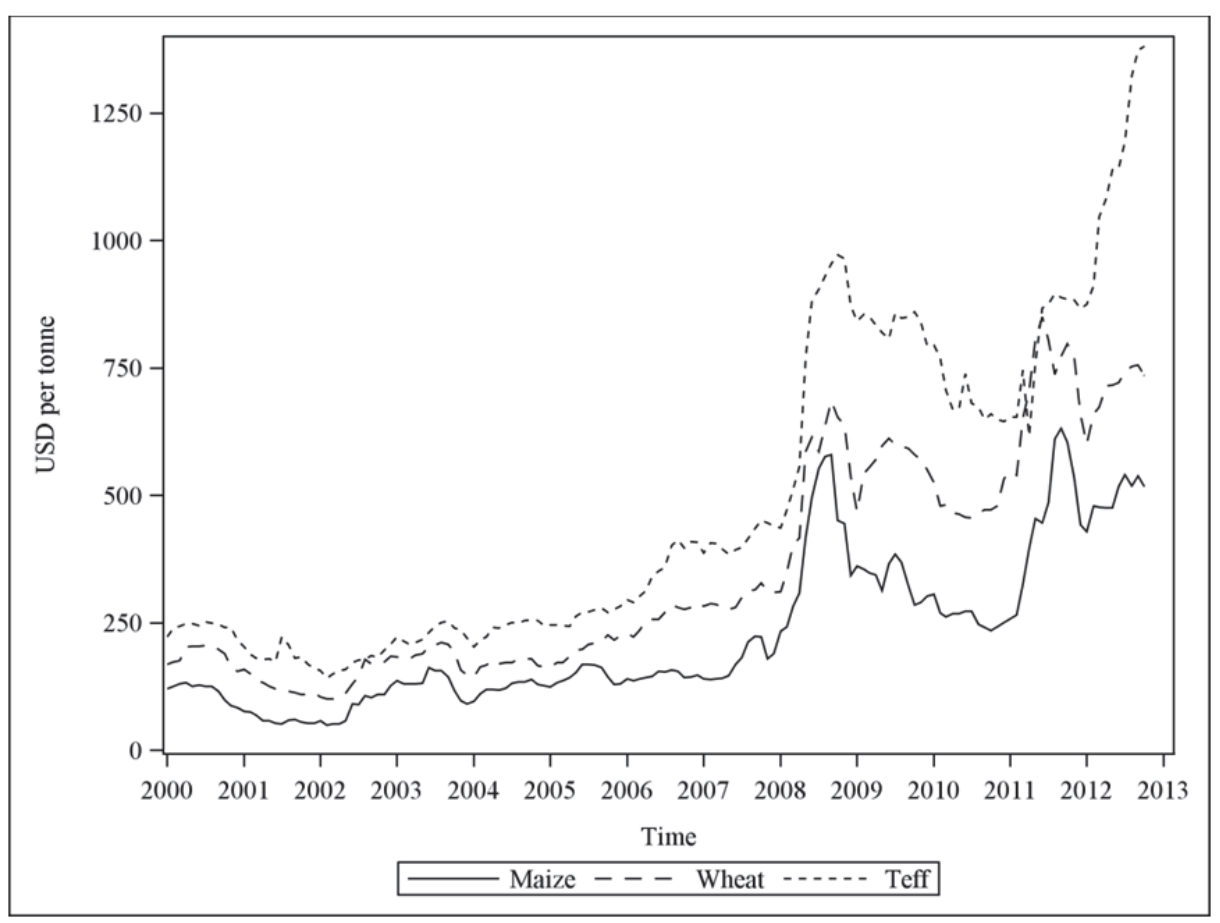

Source: FAO GIEWS food price database.

Admassie (2013: 16, Figure 3.3) presents another piece of interesting evidence, reproduced here using data from FAO. Figure 10 shows a relatively close relationship between different Ethiopian cereal prices-indeed the maize and wheat prices appear to be much more closely related to each other than their respective international counterparts. This is consistent with the explanation of food prices being driven by inflationary monetary policy. But it could also indicate an additional (and sometimes forgotten) channel of price transmission. Price increases in one grain commodity are 
likely to spill-over to other related commodities as demand shifts from more expensive to cheaper staples.

In Ethiopia, this mechanism appears to be quite strong. Rashid (2011) finds a close relationship between the wheat and maize prices, but the correlation between these and the teff price is limited. Furthermore, his analysis suggests that transmission from maize to wheat is stronger than vice versa. It is possible that whatever influence the global cereal markets have on the Ethiopian prices, it works through a single commodity rather than through multiple commodities simultaneously.

Nigeria has not been studied as closely as Ethiopia and less data is available. However, there appears to be many similarities to the Ethiopian case. Nigeria is self-sufficient in maize, yet maize prices spiked along with (and greatly surpassing) the international price during the 2008 food price crisis (see Figure 9). However, unlike Ethiopia, Nigeria also experienced a surge in maize prices in 2005 that was almost as large in nominal terms as the one in 2008. This earlier price spike occurred at a time where international prices were relatively stable which suggests that the Nigerian maize prices are predominantly driven by domestic factors. There was no obvious shortfall in production in 2005, but there was a small surplus in 2006-equivalent to 10 per cent of production (FAOSTAT 2013a). It is possible that a part of the price spikes in 2005 and 2008 reflects unusually low prices in 2006 and 2007, following an increase in production in 2006.

Nigeria imports a substantial part of its rice consumption, but unfortunately no data on the Nigerian rice prices were available on a monthly basis. Yearly averages presented by Olomola (2012) show that rice prices also rose in 2008, but more detailed price transmission patterns cannot be established for rice. 
Figure 11: Maize prices in Malawi and Zambia

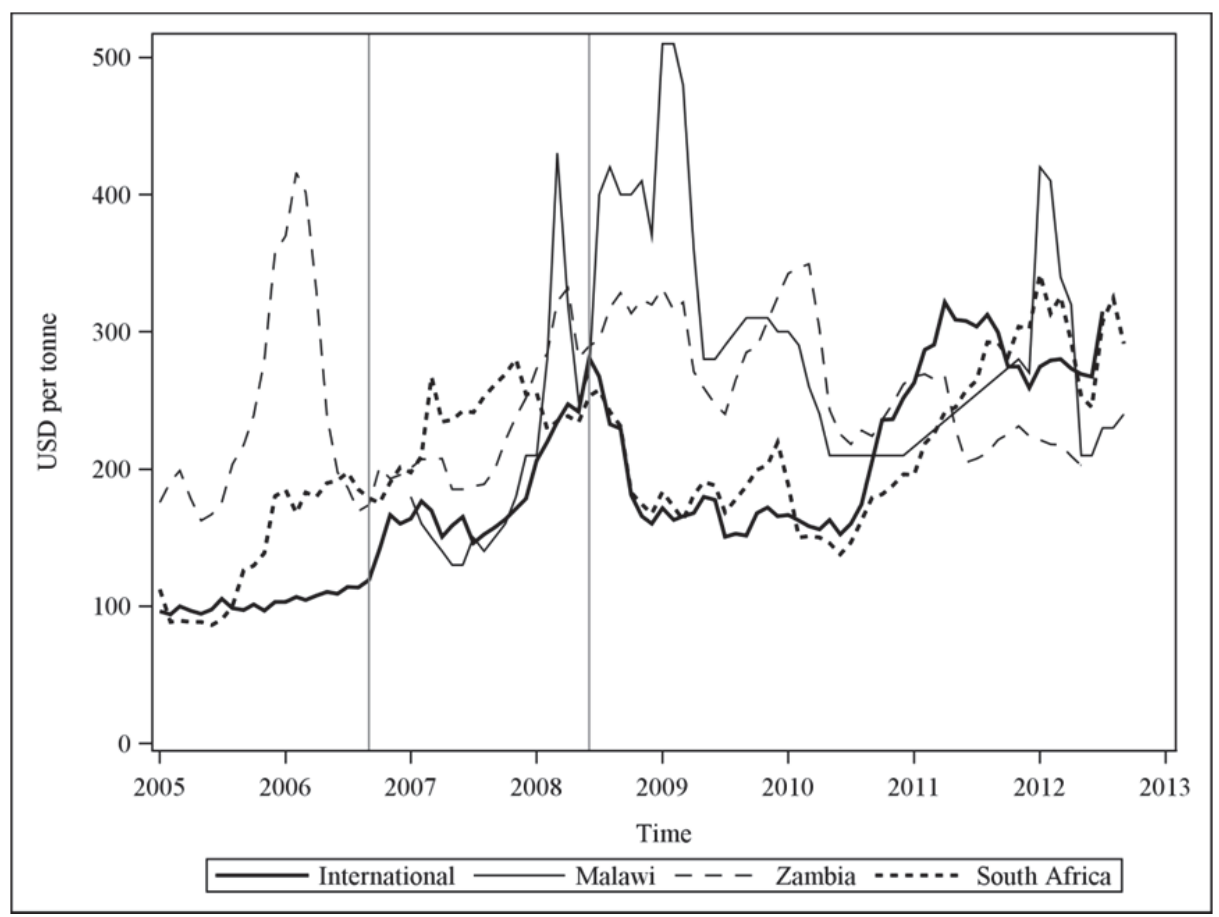

Source: FAO GIEWS food price database. International: US Gulf, no. 2, yellow maize. Malawi: Lilongwe, retail. Zambia: national average, white maize, retail. South Africa: Randfontain, white maize, wholesale.

The maize prices in Malawi and Zambia are depicted in Figure 11 along with the international price and the regional reference price in South Africa. Both the domestic price series show an upward trend during the food crisis period, but generally the prices display a relatively high volatility and do not show any obvious relationship with any of the reference prices. Minot (2011) finds weak (insignificant) long-run links between the international prices and a few of the local Malawian markets close to the border, but no evidence of any long-run relationship between the Zambian and international prices. Both countries face very high international trade costs and international trade in maize is strictly under the control of the government (Chapoto 2012; Chirwa and Chinsinga 2013). They both have a history of relatively frequent food crises during which local maize prices increase rapidly relative to international prices, latest in 2005-06. All this suggests that prices are mainly determined by domestic factors and that international prices should play a very limited role.

Malawi experienced good weather and a bountiful harvest in 2007 (the surplus was smaller, but still positive in 2008). Zambia faced flooding in parts of the country and output declined slightly in both 2007 and 2008, compared to 2006. However, 2006 was a good year, and harvests in 2007 and 2008 were still in line with a long-term upward trend (FAOSTAT 2013a). Chirwa and Chinsinga (2013) and Chapoto (2012) suggest that the local crisis was largely precipitated by government mismanagement combined with private hoarding behaviour. In Malawi, very poor quality of information about the domestic maize supply led the private sector to believe that there was shortage of maize, inducing speculative hoarding of maize in anticipation of higher prices in the future. In response to the initial price increases, the government banned exports (and cancelled a partially filled export agreement with Zimbabwe) and tried to restrict private domestic trading in an effort to control prices. These initiatives merely reinforced the signals of supply shortages and led to more intensive hoarding of maize. In Zambia, reports of flooding initiated the increase in maize prices, and as the government responded by banning exports, speculative forces similar to those in Malawi added to the price pressure. 
Although there appears to be little direct relationship between the global food crisis and the local crises experienced in Malawi and Zambia, it is possible that the high global prices acted as catalysts for the local market tensions. Chirwa and Chinsinga (2013) and Chapoto (2012) suggest that the local maize prices were largely driven by hoarding, driven by expectations of higher prices. It is possible that these expectations were also influenced by the global food outlook, just as the global food crisis could have inspired greater unease among the government officials and prompted them to misjudge the appropriate policy response.

\section{Conclusion}

Drawing a few general conclusions from fourteen very different stories on how the global food crisis was experienced and managed is not an easy task. Yet, it is possible to identify certain patterns shared by several of the countries. Here are the most important ones: the synthesis categorized the fourteen countries according to their trade status to generate predictions regarding the price transmission patterns. The four categories are:

1. Free traders: as well-integrated and open agricultural economies, Brazil and South Africa were expected to exhibit a relatively large degree of price transmission. The evidence presented here is consistent with this prediction, although the close relationship between the South African and international maize price is sometimes masked by changes in trade status (between exporter and importer), which cause the domestic price to shift between export and import parity.

2. Exporting stabilizers: China, India, and Vietnam are exporters of rice, and they all have effective state-control over exports. Although the countries' strong exporter status should generate a close relationship between domestic and international prices, effective price stabilization policies (primarily in the form of export restrictions) were expected to reduce price transmission substantially in the time of crisis. This prediction is strongly supported in the cases of China and India, but the Vietnamese retail rice prices showed a surprisingly strong pass-through of international prices, despite export restrictions.

3. Importers: of the fourteen countries in the sample, Bangladesh, Egypt, Kenya, Mozambique, and Senegal are consistently dependent upon imports of their main staple. Unlike exporters, the import dependent countries have few stabilizing policies available, and price transmission was therefore expected to be substantial. However, the evidence painted a rather mixed picture. While Bangladesh managed to contain domestic rice prices at relatively low levels (indeed, price pass-through was smaller than in Vietnam), domestic prices in Kenya, Mozambique, and Senegal rose rapidly during the crisis and stayed high long after the international crisis had subsided. Egypt appears to have been greatly affected by the food crisis as well, but the evidence is more difficult to evaluate due to data limitations.

4. The isolated: Ethiopia, Nigeria, Malawi, and Zambia are poorly integrated with the international cereal markets and are largely self-sufficient in their main staple. Due to these countries' relatively isolated status, we should expect domestic prices to be independent from the international prices. It is therefore striking to observe that they all faced rapidly increasing domestic prices during the food crisis period. In Ethiopia and Nigeria, the maize price spike surpassed the international prices by several orders of magnitude, and Malawi and Zambia experienced persistently high prices.

The synthesis discusses two overall reasons for why we observed unexpected price transmission patterns: issues related to the implementation of policies and various domestic factors. 
Although food price policies aimed at controlling local prices were implemented in most countries, they were not equally effective everywhere. Export bans were not always binding (e.g. Ethiopia and Kenya), and in Vietnam export restrictions were reportedly designed to counter a perceived domestic shortfall rather than the international crisis. Suspended import tariffs were often already low, particularly in import dependent countries (e.g., Bangladesh, Egypt, Mozambique, and Senegal), and release of grain from strategic reserves often involved relatively small quantities and/or appeared to have been neutralized by private stockpiling (e.g., Bangladesh, China, Ethiopia, and India). Many of the policies, particularly food subsidies and tax exemptions, represented a heavy drain on government finances and were unsustainable in the long term (as acutely felt in Egypt, Malawi, and Senegal). Also, many of the case studies suggest that government mismanagement rendered policies less effective or even exacerbated the crisis (Nigeria, Malawi, Senegal, and Zambia).

It is difficult to evaluate to what extent the local price shocks reflected domestic factors or were driven by the global crisis. On the one hand, it is remarkable that almost all of the countries experienced domestic price shocks that coincided with the global price spike (sometimes with a short time lag), even those (such as Ethiopia, Nigeria, Kenya, and Mozambique) that empirical research suggests are poorly integrated with the world markets. On the other hand, correlation is not the same as causation and certain signs indicate that domestic factors must have played a primary role in many countries. In Ethiopia, Kenya, Nigeria, and Mozambique, local shocks were much greater than the global shock, and it is hard to explain how price transmission alone could have generated such a major local price response. In Egypt, Malawi, and Zambia, the domestic prices spiked during the food crisis period, but apart from that, local prices show very little obvious relationship to international prices. Also, several of these countries, including Nigeria, Mozambique, and Zambia have earlier experienced episodes of great price volatility that were clearly not related to international prices. It is also possible to identify local supply constraints that can explain a substantial part of the local price shocks: harvest failures in Kenya and Senegal, flooding in parts of Mozambique and Zambia, generally tight markets combined with inflationary policies in Ethiopia, and poorly designed and implemented food policies in Malawi, Senegal, and Zambia. On a more positive note, a domestic supply response may also explain why the food crisis in Bangladesh was relatively benign: a bumper harvest was beginning to hit the markets just as international rice prices spiked.

The synthesis points towards a few issues, which could warrant closer and more systematic investigation. Here, I provide two suggestions:

First, market integration implies that local shocks are defused across global markets through international price transmission. If local shocks are large, this would involve substantial changes in trade patterns. Some of the studies in the sample suggest that large changes in trade patterns may be difficult to absorb in the short term. For instance, Bangladesh could not suddenly shift from rice import to export when the international price went above export parity, and price transmission was limited. Kenya experienced consecutive seasons of drought leading to a massive expansion in import needs. It took a very long time to fill those import orders, even after the global crisis had subsided, and the relatively high prices persisted for an extended period of time. To which extent (if any) does such trade pattern inertia affect price transmission? And does this create a price transmission asymmetry between small and large price shocks?

Second, the example of Ethiopia indicates that cross-commodity price transmission between different cereals could be an important channel for international price transmission as well. It is possible that global price shocks influence non-traded commodities indirectly through demand substitution between traded and non-traded commodities. However, evidence presented by Abbott and Borot de 
Battisti (2011) shows that this is by no means a general finding. So what role does cross-commodity price transmission play and can it explain some of the more curious price transmission patterns we have seen during the global food crisis of 2007-08?

\section{References}

Abbott, P., and A. Borot de Battisti (2011). 'Recent Global Food Price Shocks: Causes, Consequences and Lessons for African Governments and Donors'. Journal of African Economies, 20(suppl 1): i12-i62.

Adam, C. (2011). 'On the Macroeconomic Management of Food Price Shocks in Low-income Countries'. Journal of African Economies, 20(suppl 1): i63-i99.

Admassie, A. (2013). 'The Political Economy of Food Price: The Case of Ethiopia'. WIDER Working Paper 2013/001. Helsinki: UNU-WIDER.

Anderson, J.E., and E. van Wincoop (2004). 'Trade Costs'. Journal of Economic Literature, 42(3): 691-751.

Arndt, C., R. Benfica, N. Maximiano, A.M.D Nucifora, and J.T. Thurlow (2008). 'Higher Fuel and Food Prices: Impacts and Responses for Mozambique’. Agricultural Economics, 39: 497-511.

Baffes, J., and B. Gardner (2003). 'The Transmission of World Commodity Prices to Domestic Markets Under Policy Reforms in Developing Countries'. The Journal of Policy Reform, 6(3): 159-80.

Baffes, J., and T. Haniotis (2010). 'Placing the Recent Commodity Boom into Perspective'. In M.A. Aksoy and B. Hoekman (eds), Food Prices and Rural Poverty. Washington, DC: World Bank.

Benson, T., S. Mugarura, and K. Wanda (2008). 'Impacts in Uganda of Rising Global Food Prices: The Role of Diversified Staples and Limited Price Transmission'. Agricultural Economics, 39: 513-24.

Bryan, S.R. (2013). 'A Cacophony of Policy Responses. Evidence from Fourteen Countries During the 2007/08 Food Price Crisis’. WIDER Working Paper 2013/029. Helsinki: UNU-WIDER.

Chapoto, A. (2012). 'The Political Economy of Food Price Policy: The Case of Zambia'. WIDER Working Paper 2012/100. Helsinki: UNU-WIDER.

Chirwa, E.W., and B. Chinsinga (2013). 'The Political Economy of Food Price Policy: Case of Malawi’. WIDER Working Paper 2013/030. Helsinki: UNU-WIDER.

Conforti, P. (2004). 'Price Transmission in Selected Agricultural Markets'. Commodity and Trade Policy Research Working Paper 7. Rome: FAO.

Cudjoe, G., C. Breisinger, and X. Diao (2010). 'Local Impacts of a Global Crisis: Food Price Transmission, Consumer Welfare and Poverty in Ghana’. Food Policy, 35(4): 294-302.

Dawe, D. (2008). 'Have Recent Increases in International Cereal Prices Been Transmitted to Domestic Economies? The Experience in Seven Large Asian Countries'. ESA Working Paper 3. Rome: FAO.

Dawe, D. (2010). ‘Can the Next Rice Crisis Be Prevented?’. In D. Dawe (ed.), The Rice Crisis: Markets, Policies and Food Security. London and Washington, DC: FAO and Earthscan.

de Janvry, A., and E. Sadoulet (2010). 'The Global Food Crisis and Guatemala: What Crisis and for Whom?’. World Development, 38(9): 1328-39. 
Demeke, M., G. Pangrazio, and M. Maetz (2011). 'Country Responses to Turmoil in Global Food Markets: The Nature and Preliminary Implications of the Policies Pursued in the 2006-08 Episode’. In A. Prakash (ed.), Safeguarding Food Security in Volatile Global Markets. Rome: FAO.

Fackler, P.L., and B.K. Goodwin (2001). 'Spatial Price Analysis'. In B.L. Gardner and G.C. Rausser (eds), Handbook of Agricultural Economics, vol. 1, Part 2. Amsterdam: Elsevier.

FAO GIEWS (2013). 'Global Information and Early Warning System; Food Price Data and Analysis Tool'. Rome: FAO.

FAO/WFP (2009). 'Special report: Crop and Food Security Assessment Mission to Ethiopia'. Rome: FAO/WFP.

FAOSTAT. (2013a). 'Food Balance Sheets'. Rome: FAO.

FAOSTAT (2013b). ‘Trade database, Crops and Livestock Products’. Rome: FAO.

FEWS NET (2009). ‘Mozambique Food Security Outlook’. FEWS NET and USAID.

Ganguli, K., and A. Gulati (2013). 'The Political Economy of Food Price Policy, India Case Study'. WIDER Working Paper 2013/(forthcoming). Helsinki: UNU-WIDER.

Ghoneim, A.F. (2012). 'The Political Economy of Food Price Policy in Egypt'. WIDER Working Paper 2012/096. Helsinki: UNU-WIDER.

Nguyen, M.H. (2013). 'The Political Economy of Food Price Policy: The Case of Rice and Maize in Vietnam’. WIDER Working Paper 2013/(forthcoming). Helsinki: UNU-WIDER.

Haji, J., and F. Gelaw (2012). 'Determinants of the Recent Soaring Food Inflation in Ethiopia'. Universal Journal of Education and General Studies, 1(8): 225-33.

Headey, D., and S. Fan (2010). 'Reflections on the Global Food Crisis'. Washington, DC: IFPRI.

Headey, D., F.B. Nisrane, I. Worku, M. Dereje, and A.S. Taffesse (2012). 'Urban Wage Behaviour and Food Price Inflation: The Case of Ethiopia'. Ethiopia Strategy Support Programme II Working Paper 41. Addis Ababa: IFPRI and EDRI.

Hossain, M., and U. Deb (2010). 'Volatility in Rice Prices and Policy Responses in Bangladesh'. In D. Dawe (ed.), The Rice Crisis: Markets, Policies and Food Security. London and Washington, DC: FAO and Earthscan.

Huang, J., J. Yang, and S. Rozelle (2013). 'The Political Economy of Food Price Policy in China'. WIDER Working Paper 2013/(forthcoming). Helsinki: UNU-WIDER.

Hummels, D., and A. Skiba (2004). 'Shipping the Good Apples Out? An Empirical Confirmation of the Alchian-Allen Conjecture'. Journal of Political Economy, 112(6): 1384-402.

Kirsten, J.F. (2012). 'The Political Economy of Food Price Policies in South Africa'. WIDER Working Paper 2012/102. Helsinki: UNU-WIDER.

Loening, J.L., D. Durevall, and J.A. Birru (2009). 'Inflation Dynamics and Food Prices in an Agricultural Economy: The Case of Ethiopia’. Policy Research Working Paper 347. Washington, DC: World Bank.

Martin, W., and K. Anderson (2012). 'Export Restrictions and Price Insulation During Commodity Price Booms’. American Journal of Agricultural Economics, 94(2): 422-27.

Meyer, J., and S. von Cramon-Taubadel (2004). 'Asymmetric Price Transmission: A Survey'. Journal of Agricultural Economics, 55(3): 581-611. 
Minot, N. (2011). 'Transmission of World Food Price Changes to Markets in Sub-Saharan Africa'. IFPRI Discussion Paper 1059. Washington, DC: IFPRI.

Mueller, B., and C. Mueller (2012). 'The Impact of the 2007-08 Food Price Crisis in a Major Commodity Exporter: Food Prices, Inflation, and Inclusion in Brazil’. WIDER Working Paper 2012/095. Helsinki: UNU-WIDER.

NAMC (2007). 'The South African Food Cost Review 2007’. Pretoria: NAMC.

NAMC (2009). 'The South African Food Cost Review 2009'. Pretoria: NAMC and the Department of Agriculture, Forestry and Fisheries.

Nhate, V., and C. Massingarela (2013). 'The Political Economy of Food Price Policy: Country Case Study Mozambique’. WIDER Working Paper 2013/(forthcoming). Helsinki: UNU-WIDER.

Nzuma, J.M. (2013). 'The Political Economy of Food Price Policy: Kenya Country Case'. WIDER Working Paper 2013/026. Helsinki: UNU-WIDER.

Olomola, A.S. (2013). 'The Political Economy of Food Price Policy in Nigeria'. WIDER Working Paper 2013/016. Helsinki: UNU-WIDER.

Raihan, S. (2013). 'Political Economy of Food Price Policy: The Case of Bangladesh.' WIDER Working Paper 2013/002. Helsinki: UNU-WIDER.

Rapsomanikis, G., D. Hallam, and P. Conforti (2006). 'Market Integration and Price Transmission in Selected Food and Cash Crop Markets in Sub-Saharan Africa'. In A. Sarris and D. Hallam (eds.), Agricultural Commodity Markets and Trade. New Approaches to Analyzing Market Structure and Instability. Cheltenham and Northampton, MA: Edward Elgar and FAO.

Rashid, S. (2011). 'Intercommodity Price Transmission and Food Price Policies: An Analysis of Ethiopian Cereal Markets’. IFPRI Discussion Paper 1079. Washington, DC: IFPRI.

Resnick, D. (2013). 'Personalistic Policy-Making in a Vibrant Democracy: Senegal's Fragmented Response to the 2007/08 Food Price Crisis'. WIDER Working Paper 2013/015. Helsinki: UNUWIDER.

Robles, M. (2011). 'Price Transmission from International Agricultural Commodity Markets to Domestic Food Prices: Case Studies in Asia and Latin America’. Washington, DC: IFPRI.

Tadesse, G., and A.G. Guttormsen (2011). 'The Behavior of Commodity Prices in Ethiopia'. Agricultural Economics, 42(1): 87-97.

Timmer, C.P. (2010). 'Reflections on Food Crises Past'. Food Policy, 35(1): 1-11.

Ulimwengu, J.M., S. Workneh, and Z. Paulos (2009). 'Impact of Soaring Food Price in Ethiopia'. IFPRI Discussion Paper 846. Washington, DC: IFPRI.

UN COMTRADE (2013). 'United Nations Commodity Trade Statistics Database'. Accessed throught World Integrated Trade Solution (WITS). New York: United Nations Statistics Division.

UNCTAD TRAINS (2013). 'Trade Analysis and Information Systems'. Accessed through World Integrated Trade Solution (WITS). Geneva: United Nations Conference on Trade and Development.

Watson, D.D. II. (2013). 'Political Economy Synthesis: The Food Policy Crisis'. WIDER Working Paper 2013/(forthcoming). Helsinki: UNU-WIDER. 